\title{
Spina Bifida and Anencephalus in Greater London
}

\author{
C. O. CARTER and KATHLEEN EVANS \\ MRC Clinical Genetics Unit, Institute of Child Health, 30 Guilford St, London WC1N 1EH
}

Summary. In order to make comparisons with the findings in a high frequency area, South Wales, with those in a low frequency area, south-east England, a birth frequency and family study was made of all births with neural tube malformations (spina bifida cystica, encephalocele, anencephaly, and iniencephaly) in 32 of the 33 London Boroughs over a 3-year period from 1 April 1965 to 31 March 1968. The births were ascertained through local authority registers, stillbirth and infant death certificates, and hospital records. The frequencies found were 1.54 for spina bifida (including encephalocele) and 1.41 for anencephaly (including iniencephaly). This was less than four tenths of the South Wales frequency. Evidence of an excess of winter births was found for both types of malformation, with a peak for conceptions in February, March, and April.

The parents of 870 of the original 1209 index patients were traced and visited for the family survey. The usual social class effect was seen, a deficit of fathers in social class I and II. The birth order distribution of legitimately born patients standardized for maternal age showed only a small excess of firstborn and a deficit rather than an excess of lateborn. For maternal age, however, standardized for birth order, there was an excess of patients born to mothers under 20 and over 35 years of age. The whole family study sample showed a striking excess of patients born to parents from India and Pakistan compared to parents born in the West Indies in relation to households of immigrant parents in the 1966 sample Census. A small sample of 164 patients with matched controls had more parents born in Ireland and India and Pakistan and fewer born in south-east England and the West Indies than the controls.

The proportions of sibs affected with spina bifida and anencephaly were $3.42 \%$ for spina bifida index patients and 5.44\% for anencephaly. For patients born after the index patient the proportions were $5 \cdot 17$ and $4 \cdot 17 \%$, respectively. The overall risk to sibs was lower than that shown in the South Wales survey, but substantially higher relative to the population birth frequency. The risk to sibs was not apparently influenced by father's social class but there was an indication of an effect of mother's father's social class, with a lower risk where mother had grown up in a class I, II, or IIIa home. There was no apparent influence of grandparental birth place. There was no apparent effect of a relative affected other than a sib. Among cousins a significant increase over the population birth frequency was seen only in mother's sisters' children.

The findings, like those of earlier surveys, suggest a multifactorial aetiology of the neural tube malformations, depending both on genetic predisposition and environmental triggers.

Received 31 May 1973. 
Data on the frequency of anencephalic still births published by the Registrar General for England and Wales since 1962 show a marked regional variation with a steady fall as one passes from the NorthWest to the South-East of the country (Carter, 1969; Elwood, 1970a). For spina bifida less information is available, but local studies (Williamson, 1965; Carter, David, and Laurence, 1968; Leck et al, 1968; Elwood, 1972) indicate that the birth frequency parallels that of anencephaly.

Following a large scale birth frequency and family study in a high incidence area, South Wales, based on births from 1956 to 1962 inclusive (Carter et al, 1968; Laurence, Carter, and David, 1968a and b), a similar study has been carried out in a low incidence area, Greater London, in order to compare family risks. Data were also collected on maternal age and birth order, social class and parental birth place.

\section{BIRTH FREQUENCY STUDY Material and Methods}

Together with Miss B. Spain of the Greater London Council who was studying incidence and survival rates for neural tube defects within Greater London for a 4year period beginning 1 April 1965, an attempt was made to identify all mothers domiciled in the London area who had had a child (live or still born) with a malformation of the central nervous system between 1 April 1965 and 31 March 1968. (The frequency over the longer period will be published separately, Spain-in preparation.) It was on 1 April 1965 that the Borough boundaries were redefined at the setting up of the Greater London Council. Not all children are born in hospital so it was necessary to search for births outside as well as inside hospitals.

The statutory procedure at the birth of a child (live or still) is that the medical attendant notifies the local Medical Officer of Health, who collects information about malformed children from this notification and other sources and sends it, without identification details, to the Office of Population Censuses and Surveys; if a child is stillborn or dies soon after birth the medical attendant gives the parent a certificate which he takes to the local Registrar when registering the birth. The Registrar makes returns to the Registrar General. The Registrar General's figure for malformations in those stillborn or dying soon after birth for any area should agree with that from the Medical Officer of Health for the area.

Our main source of names was the local authority, since it was through the kind help of their medical officers of health that we had an introduction to the families. The staff of one borough only out of the 33 were unable to help and that borough was excluded. London boroughs have various systems of record keeping, but it is usual for them to make registers of abnormalities from birth notification cards and other sources, under such headings as congenital abnormalities, infant deaths, still births, at risk, and others. It was these registers and any other source of a record of an abnormality which were scrutinized to compile the list for the series. In this way 1002 names were collected.

Although the local authority totals for stillborn and dead babies should agree with those which the Registrar General receives from the local Registrar, it is well known that there is usually a deficit in the local authority figure (Weatherall, 1969; Elwood, 1970b). Accordingly, our list of names from the local authority registers was checked against the neonatal death certificates (up to 3 months) and still-birth certificates for the same area and period which the Registrar General kindly allowed us to see. There were 189 births found from the Registrar General's certificates which had not appeared in the local Health Department registers. Once the name was known from the still-birth or death certificate it was usually possible to confirm the diagnosis from the individual birth notification at the local authority and to obtain an introduction to the family. Failing this, the diagnosis was confirmed with the hospital. The names of five patients were found first from the records of maternity hospitals or those specializing in the treatment of spina bifida.

All babies born in London whose mothers were domiciled elsewhere were excluded, but babies born outside London whose mothers were domiciled in London are included. The criterion for inclusion was a diagnosis of spina bifida cystica, anencephaly, iniencephaly, or encephalocele; hydrocephalus was included only when secondary to spina bifida. For the analysis encephalocele is included with spina bifida and inien cephaly with anencephaly. Any death or still-birti certificate which recorded hydrocephalus without men tion of spina bifida or 'congenital abnormalities' was checked at the maternity hospital and if anencephaly or spina bifida was recorded they are included (13 names were found in this way). Where a baby was born at home a similar check was made with the attending doctor or midwife. Cases of spina bifida occulta are excluded. There were altogether 1209 cases.

Virtually all children born affected in the area will have been ascertained in one way or another. The first source of ascertainment is shown in Table $I$.

\section{Results}

Overall Birth Frequency. The total births for the 32 cooperating London Boroughs for the period and the numbers and proportions affected are shown in Table II.

The overall frequency of spina bifida was 1.54 and of anencephaly 1.41 per 1000 total births. The combined frequency was 2.95 per 1000 live and still births. There was no significant variation in birth frequency of either condition over the period surveyed. The rates per 1000 for the years are as follows: April to December 1965, 2.92; January to December 1966, 2.88; January to December 1967, 
TABLE I

SOURCE OF ASCERTAINMENT OF INDEX PATIENTS*

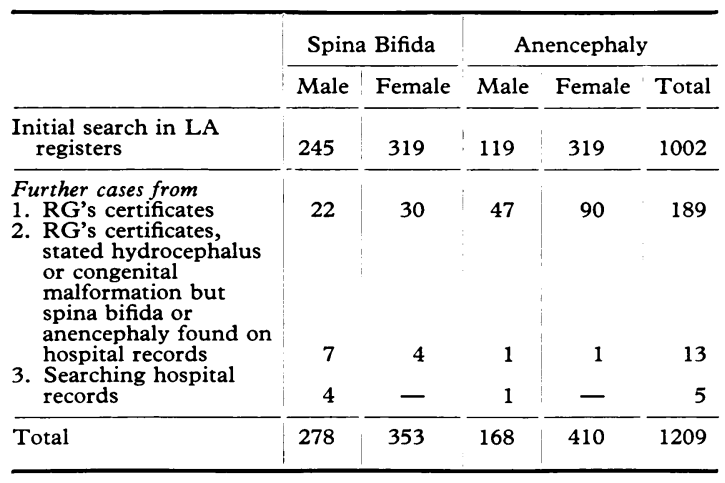

* LA = Local Authority; RG = Registrar General.

3.13, and January to March 1968 (only 3 months), $2 \cdot 62$. The total of 631 spina bifida births included 278 males and 353 females, a sex ratio of 0.79 . The total of 578 anencephalic births included 168 males and 410 females, a sex ratio of 0.41 .

Seasonal Variation. The number of patients born in each month is shown in Table III together with the expected numbers related to the monthly frequency of total births in the Greater London area (Registrar General's table 1967 TT a, unpublished).

For spina bifida the summer quarter (June, July, and August) has a relatively low incidence and the winter quarter (November, December, and January) a relatively high incidence. For anencephaly, there is a noticeable low incidence in April, May, and June and a relatively high incidence in December, January, and February. None of the differences are significant.

However, if one allows for a one month shorter
TABLE III

OBSERVED AND EXPECTED SPINA BIFIDA AND ANENCEPHALY BIRTHS IN GREATER LONDON APRIL 1965-MARCH 1968 SHOWING MONTHS OF OCCURRENCE

(Registrar General's unpublished data)

\begin{tabular}{|c|c|c|c|c|}
\hline & \multicolumn{2}{|c|}{ Spina Bifida } & \multicolumn{2}{|c|}{ Anencephaly } \\
\hline & Observed & Expected & Observed & Expected \\
\hline $\begin{array}{l}\text { Jan. } \\
\text { Feb. } \\
\text { Mar. } \\
\text { Apr. } \\
\text { May } \\
\text { June } \\
\text { July } \\
\text { Aug. } \\
\text { Sept. } \\
\text { Oct. } \\
\text { Nov. } \\
\text { Dec. }\end{array}$ & $\begin{array}{l}53 \\
52 \\
53 \\
55 \\
61 \\
55 \\
44 \\
44 \\
59 \\
36 \\
54 \\
65\end{array}$ & $\begin{array}{l}52 \cdot 59 \\
50 \cdot 22 \\
57 \cdot 20 \\
53 \cdot 77 \\
55 \cdot 23 \\
52 \cdot 71 \\
53 \cdot 99 \\
52 \cdot 66 \\
52 \cdot 50 \\
51 \cdot 37 \\
48 \cdot 11 \\
50 \cdot 65\end{array}$ & $\begin{array}{l}49 \\
53 \\
48 \\
52 \\
47 \\
39 \\
53 \\
43 \\
46 \\
51 \\
45 \\
52\end{array}$ & $\begin{array}{l}48 \cdot 18 \\
46 \cdot 01 \\
52 \cdot 39 \\
49 \cdot 26 \\
50 \cdot 59 \\
48 \cdot 28 \\
49 \cdot 46 \\
48 \cdot 23 \\
48 \cdot 09 \\
47 \cdot 05 \\
44 \cdot 07 \\
46 \cdot 40\end{array}$ \\
\hline Total & 631 & $631 \cdot 00$ & 578 & $578 \cdot 00$ \\
\hline
\end{tabular}

gestation period for anencephaly, then for both malformations combined the highest incidence is for conceptions in February, March, and April and lowest incidence for conceptions in September, October, and November. The observed distribution by estimated season of conception for spina bifida and anencephaly are shown in Table IV together with the expected distribution; also the ratio of observed and expected by month and the threemonthly running average. The latter is shown in Figure 1.

\section{FAMILY STUDY \\ Methods}

To collect the family information an attempt was made to visit every mother of an index patient to find out about her other children, nieces and nephews of her husband and herself, husband's occupation, parental age and birth places, birth places of the grandparents, and some information about the pregnancy. Altogether 771

TABLE II

TOTAL BIRTHS AND SPINA BIFIDA AND ANENCEPHALY IN 32 LONDON BOROUGHS

\begin{tabular}{|c|c|c|c|c|}
\hline & Total Births & Spina Bifida* & Anencephaly* & \multirow{2}{*}{$\begin{array}{c}\text { Total (spina } \\
\text { bifida and } \\
\text { anencephaly)* }\end{array}$} \\
\hline & Live & Female & Female & \\
\hline Apr.-Dec. 1965 & $\begin{array}{c}103,963 \\
105,516\end{array}$ & $\begin{array}{c}72 \\
159(1.507) \\
\end{array}$ & $\begin{array}{c}47 \\
149(1.412) \\
\end{array}$ & $308(2.919)$ \\
\hline Jan.-Dec. 1966 & $\begin{array}{c}137,162 \\
139,146\end{array}$ & $\begin{array}{cc}96 & 115 \\
211(1.516) \\
\end{array}$ & $\begin{array}{c}57 \\
190(1.366) \\
\end{array}$ & $401(2 \cdot 882)$ \\
\hline Jan.-Dec. 1967 & $\begin{array}{c}130,620 \\
132,373^{1753}\end{array}$ & $\begin{array}{c}95 \quad 123 \\
218(1.647) \\
\end{array}$ & $\begin{array}{cc}54 & 143 \\
197(1.488)\end{array}$ & $415(3 \cdot 135)$ \\
\hline Jan.-Mar. 1968 & ${ }_{32,431} 451$ & $\begin{array}{c}15 \quad 28 \\
43(1 \cdot 326) \\
\end{array}$ & $\begin{array}{c}10 \quad 32 \\
42(1 \cdot 295) \\
\end{array}$ & $85(2.621)$ \\
\hline Total & 409,466 & $\begin{array}{cc}278 & 353 \\
631 & (1.541)\end{array}$ & $\begin{array}{cr}168 & 410 \\
578(1.412)\end{array}$ & $1209(2.953)$ \\
\hline
\end{tabular}

* The rate per 1000 births is given in parentheses. 
TABLE IV

OBSERVED AND EXPECTED SPINA BIFIDA AND ANENCEPHALY BIRTHS BY ESTIMATED MONTH OF CONCEPTION

\begin{tabular}{l|c|c|c}
\hline & Observed & Expected & Obs/Exp \\
\cline { 2 - 3 } & 82 & 98.42 & 0.83 \\
Jan. & 105 & 92.18 & 1.14 \\
Feb. & 110 & 97.05 & 1.13 \\
Mar. & 105 & 100.77 & 1.04 \\
Apr. & 101 & 96.23 & 1.05 \\
May & 106 & 109.59 & 0.97 \\
June & 103 & 103.03 & 1.00 \\
July & 113 & 105.82 & 1.07 \\
Aug. & 102 & 100.99 & 1.01 \\
Sept. & 183 & 103.45 & 0.80 \\
Oct. & 97 & 100.89 & 0.96 \\
Nov. & 102 & 100.59 & 1.01 \\
Dec. & & & \\
\hline
\end{tabular}

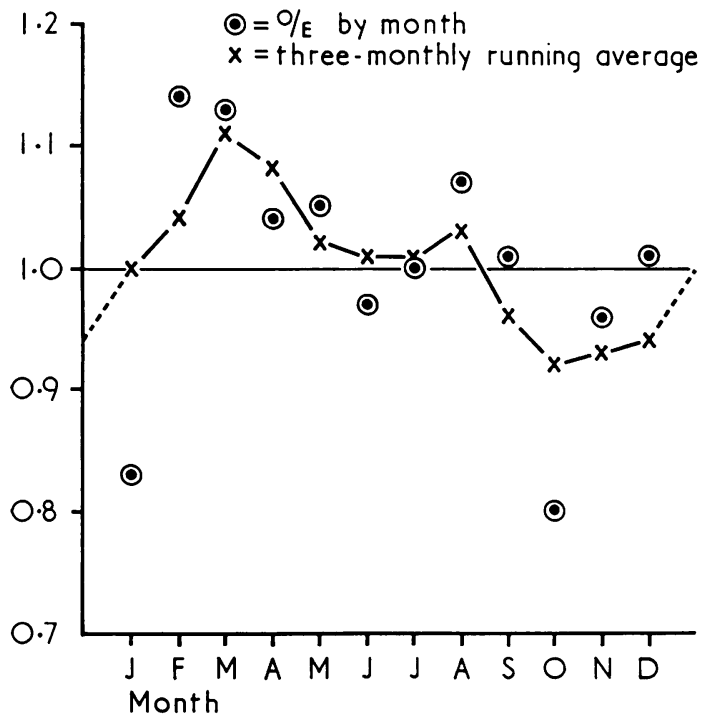

FIG. 1. Distribution ratio of observed $(O)$ spina bifida and anencephaly births over expected $(E)$ births by month of conception.

families were visited in this way by one of the three social workers taking part in the study. These families, the main series, for which full information was obtained are called group 1 (Appendix I).

For a subsidiary series of 99 , called group 2 (Appendix II) more limited information, always including the details of the mother's other births, was available. Included in this group were 64 patients already being visited at home by Miss Spain, the psychologist working for the Greater London Council who collaborated in collecting family information; 22 patients born in one borough where the Medical Officer of Health preferred that his Health Visitors carried out the interview; 13 where the Unit social workers were able to collect limited family information only.

The family survey is therefore based on 870 patients, $72 \%$ of the total sample.

The 339 patients whose families were not interviewed included 43 whose parents refused to take part; 35 where the family doctor or Medical Officer of Health thought a visit to the family inadvisable, and 261 whose families were never traced. The rather high proportion untraced is related to the fact that about half the patients were still born. The reasons for failure to trace included: inadequate initial address, frequent change of address, migration out of the United Kingdom, and adoption.

Where a sib or cousin of the patient was reported to be affected, confirmation was obtained from hospital records, still-birth or death certificates. Miscarriages are not included in the analysis (or Appendices I and II), although it is stated in the text where it is known that a miscarriage had a neural tube malformation.

\section{Results}

Social Class. The patient's father's occupation was recorded for the 771 patients in the main series and the 64 visited by the GLC psychologist. The mothers of 10 patients (mostly illegitimate) did not know the occupation of the father.

The social class distribution of fathers of index patients was compared (Table V) with that for all adult males in Greater London in the 1961 Census (Table 27). There is a significant deficit of observed cases (127) compared with expected cases $(170.52)$ in social classes I and II. This deficit would almost certainly have been larger if it had been possible to include the families which were not traced. There is also a small and nonsignificant deficit in classes IV and V, but this may well be due to the omission of those families not traced.

TABLE $\mathrm{V}$

DISTRIBUTION OF FATHERS' SOCIAL CLASS (O) COMPARED WITH THAT FOR ALL MEN IN GREATER LONDON (E). FROM 1961 CENSUS

\begin{tabular}{|c|c|c|c|c|c|c|c|}
\hline \multirow{2}{*}{ Class } & \multicolumn{6}{|c|}{ Social Class } & \multirow{2}{*}{$\begin{array}{c}\text { Total } \\
\text { (exclud- } \\
\text { ing } \\
\text { not } \\
\text { known) }\end{array}$} \\
\hline & I & II & III & IV & V & $\underset{\text { Known }}{\text { Not }}$ & \\
\hline$\underset{\mathbf{E}}{\mathbf{O}}$ & $\begin{array}{l}34 \\
40.03\end{array}$ & $\begin{array}{c}93 \\
130 \cdot 49\end{array}$ & $\begin{array}{l}490 \\
434 \cdot 21\end{array}$ & $\begin{array}{l}148 \\
146 \cdot 11\end{array}$ & $\begin{array}{l}60 \\
74 \cdot 16\end{array}$ & 10 & 825 \\
\hline
\end{tabular}

Maternal Age and Birth Order. The maternal age and birth order distribution of the legitimate index patients was compared with the expected number estimated from the distribution of all legitimate births in Greater London in 1967 (Registrar General, unpublished). The comparison is shown in Table VI. The distribution by maternal age standardized for birth order, and birth order standardized for maternal age is shown in Table VII. It will be seen from Table VI that the most striking excess of observed over expected, 75 as compared with 48.95 , is for first born children to 
TABLE VI

DISTRIBUTION BY MATERNAL AGE AND NUMBER OF PREVIOUS LIVE BORN SIBS OF LEGITIMATE INDEX PATIENTS COMPARED WITH EXPECTED DISTRIBUTION (E) FOR ALL LEGITIMATE BIRTHS IN GREATER LONDON (Registrar General's figures 1967, unpublished)

\begin{tabular}{|c|c|c|c|c|c|c|c|}
\hline \multirow{2}{*}{ Maternal Age (yr) } & \multicolumn{6}{|c|}{ Birth Order } & \multirow{2}{*}{ Total } \\
\hline & 0 & 1 & 2 & 3 & 4 & 5 & \\
\hline $\begin{array}{c}15-19 \\
\mathrm{O} \\
\mathrm{E}\end{array}$ & $\begin{array}{l}75 \\
48 \cdot 95\end{array}$ & $\stackrel{9}{10 \cdot 43}$ & $\begin{array}{l}0 \\
1 \cdot 18\end{array}$ & $\begin{array}{l}0 \\
0.07\end{array}$ & $\begin{array}{l}0 \\
0.01\end{array}$ & $\begin{array}{l}0 \\
0.00\end{array}$ & $\begin{array}{l}84 \\
60 \cdot 64\end{array}$ \\
\hline $\begin{array}{c}20-24 \\
\mathrm{O} \\
\mathrm{E}\end{array}$ & $\begin{array}{l}170 \\
163.45\end{array}$ & $\begin{array}{l}80 \\
88 \cdot 11\end{array}$ & $\begin{array}{l}22 \\
25 \cdot 48\end{array}$ & $\begin{array}{l}6 \\
7 \cdot 11\end{array}$ & $\begin{array}{l}1 \\
1 \cdot 64\end{array}$ & $\begin{array}{l}0 \\
0.52\end{array}$ & $\begin{array}{l}279 \\
286 \cdot 31\end{array}$ \\
\hline $\begin{array}{c}25-29 \\
\mathrm{O}\end{array}$ & $\begin{array}{l}81 \\
90.02\end{array}$ & $\begin{array}{l}93 \\
92 \cdot 41\end{array}$ & $\begin{array}{l}53 \\
48 \cdot 07\end{array}$ & $\begin{array}{l}19 \\
19 \cdot 30\end{array}$ & $\begin{array}{l}6 \\
7 \cdot 69\end{array}$ & $\begin{array}{l}1 \\
4 \cdot 41\end{array}$ & $\begin{array}{l}253 \\
261 \cdot 89\end{array}$ \\
\hline $\begin{array}{c}30-34 \\
\mathrm{O} \\
\mathrm{E}\end{array}$ & $\begin{array}{l}41 \\
32 \cdot 50\end{array}$ & $\begin{array}{l}31 \\
42 \cdot 68\end{array}$ & $\begin{array}{l}25 \\
32 \cdot 89\end{array}$ & $\begin{array}{l}18 \\
18.09\end{array}$ & $\begin{array}{l}5 \\
8 \cdot 84\end{array}$ & $\begin{array}{l}4 \\
8 \cdot 84\end{array}$ & $\begin{array}{l}124 \\
143 \cdot 85\end{array}$ \\
\hline $\begin{array}{c}35-39 \\
\mathrm{O} \\
\mathrm{E}\end{array}$ & $\begin{array}{l}15 \\
12.05\end{array}$ & $\begin{array}{l}10 \\
14.64\end{array}$ & $\begin{array}{l}21 \\
15.09\end{array}$ & $\stackrel{9}{10 \cdot 54}$ & $\begin{array}{l}9 \\
6 \cdot 67\end{array}$ & $\begin{array}{l}8 \\
8 \cdot 55\end{array}$ & $\begin{array}{l}72 \\
67 \cdot 54\end{array}$ \\
\hline $\begin{array}{r}40+ \\
\mathrm{O} \\
\mathrm{E}\end{array}$ & $\begin{array}{l}6 \\
2 \cdot 94\end{array}$ & $\begin{array}{l}3 \\
2 \cdot 88\end{array}$ & $\begin{array}{l}8 \\
3 \cdot 56\end{array}$ & $\begin{array}{l}3 \\
3 \cdot 24\end{array}$ & $\begin{array}{l}4 \\
2 \cdot 00\end{array}$ & $\begin{array}{l}3 \\
4 \cdot 16\end{array}$ & $\begin{array}{l}27 \\
18 \cdot 77\end{array}$ \\
\hline Total & $\begin{array}{l}388 \\
349 \cdot 91\end{array}$ & $\begin{array}{l}226 \\
251 \cdot 13\end{array}$ & $\begin{array}{l}129 \\
126 \cdot 27\end{array}$ & $\begin{array}{l}55 \\
58 \cdot 35\end{array}$ & $\begin{array}{l}25 \\
26 \cdot 85\end{array}$ & $\begin{array}{l}16 \\
26 \cdot 49\end{array}$ & 839 \\
\hline
\end{tabular}

mothers under the age of 20 years. The birth order distribution standardized for maternal age (Table VIIa) shows no significant deviation from the expected figures; it is noteworthy that though there is a small excess of first born, and a deficit of late born, it is possible that a higher proportion of first born were present among the legitimately born patients who were not traced. The observed maternal age distribution (Table VIIb), however, deviates from the expected at the 1 in 100 level of significance; the

TABLE VIIa

DISTRIBUTION BY NUMBER OF PREVIOUS LIVE BORN SIBS STANDARDIZED FOR MATERNAL AGE

\begin{tabular}{c|c|c|c|c|c|c|c}
\hline & \multicolumn{6}{|c|}{ Birth Order } & \multirow{2}{*}{ Total } \\
\cline { 2 - 7 } & 0 & \multicolumn{1}{|c|}{1} & \multicolumn{1}{|c}{2} & 3 & 4 & $5+$ & \\
\hline $\mathrm{O}$ & 388 & 226 & 129 & 55 & 25 & 16 & 839 \\
$\mathrm{E}$ & $359 \cdot 14$ & $246 \cdot 10$ & $122 \cdot 46$ & $57 \cdot 16$ & 26.65 & $27 \cdot 49$ & \\
\hline
\end{tabular}

TABLE VIIb

DISTRIBUTION BY MATERNAL AGE STANDARDIZED FOR BIRTH ORDER

\begin{tabular}{l|l|l|l|l|l|l|l}
\hline & \multicolumn{6}{|c|}{ Maternal Age } & \multirow{2}{*}{ Total } \\
\hline & $15-19$ & $20-24$ & $25-29$ & $30-34$ & $35-39$ & $40+$ & \\
\hline O & 84 & 279 & 253 & 124 & 72 & 27 & 839 \\
E & $64 \cdot 16$ & $293 \cdot 10$ & $260 \cdot 26$ & $139 \cdot 83$ & $64 \cdot 32$ & $17 \cdot 34$ & \\
\hline
\end{tabular}

excess of observed over expected is for mothers of index patients both under the age of 20 and over the age of 35 years.

Place of Birth of Parents and Grandparents. No figure for all Greater London births was available with which to compare the distribution of parental birth places of our index patients. However in the 1966 sample Census a table (Commonwealth Immigrant Tables, Table 18) is given showing the distribution for Greater London of households with children by birthplace of head and spouse where this was in the old or the new Commonwealth. The two large groups are parents born in India and Pakistan and those born in the West Indies. The comparison for those two areas for the parents of index patients is shown in Table VIII. This shows a significant deficit of parents of

TABLE VIII

RELATIVE FREOUENCY WITH WHICH BOTH PARENTS OF PATIENTS WERE BORN IN INDIA AND PAKISTAN AND THE WEST INDIES COMPARED WITH THAT FOR ALL HOUSEHOLDS WITH CHILDREN IN GREATER LONDON (SAMPLE CENSUS 1966)

\begin{tabular}{l|c|c|c}
\hline & $\begin{array}{c}\text { India and } \\
\text { Pakistan }\end{array}$ & West Indies & $\begin{array}{c}\text { India/ } \\
\text { West Indies }\end{array}$ \\
\cline { 1 - 2 } $\begin{array}{l}\text { Parents of patients } \\
\text { All households }\end{array}$ & 25 & 23 & $\begin{array}{c}1.09 \\
0.26\end{array}$ \\
\hline
\end{tabular}


index patients born in the West Indies and an excess born in India and Pakistan.

A separate smaller scale, but better controlled, comparison may be made for 164 index patients who were matched with an equal number of control births (those immediately following in the same maternity unit). The homes of these controls were also visited. The findings for parents are shown in Table IX. The differences are not significant. However, more parents of patients than of controls were born in India and Pakistan and fewer in South-East England and the West Indies.

The grandparental birth places gave no additional information.

TABLE IX

PARENTAL BIRTHPLACES OF INDEX PATIENTS AND CONTROLS WHEN BOTH PARENTS WERE BORN IN THE SAME REGION

\begin{tabular}{l|c|c}
\hline \multicolumn{1}{c|}{ Birthplace } & Index Patients & Controls \\
\hline Ireland & 15 & 10 \\
India and Pakistan & 6 & 3 \\
North and West Britain, Scotland, & 5 & 5 \\
and Wales & 82 & 108 \\
South-East England & 5 & 8 \\
West Indies & 51 & 30 \\
Others & & \\
\hline
\end{tabular}

Consanguinity of Parents. In the whole series only five index patients were born to consanguineous parents, and in no case were the parents native born. In three instances (two first cousins and one first cousin once removed) the parents were born in India, in one instance (first cousin) parents were born in Ireland, and in one instance (second cousin) the parents were born in Aden. In these five families none of the 11 sibs of the index patients had a neural tube malformation.

Twins. The information on twins is summarized in Table $\mathrm{X}$; this includes two twin born index patients whose families were not visited. Of four twin born index patients with spina bifida, one male (No. 31) had a normal female twin, two females (No. 360 and an unvisited encephalocele) had normal male twins, and one female (No. 327) had a normal female twin. Of 11 twin born index patients with anencephaly, one male (No. 491) had a female twin with anencephaly (No. 755) and one male (unvisited) had a normal male twin; one female (No. 755) had a male twin with anencephaly (No. 491), three females (Nos. 733, 701, and 702) had male twins without central nervous system malformation, but two of these died neonatally, one with atresia of the aorta and one from prematurity; five other females (Nos. 670, 605, 576, 499, and 500) had
TABLE $\mathrm{X}$

TWIN BORN INDEX PATIENTS

\begin{tabular}{|c|c|c|c|c|c|}
\hline \multicolumn{3}{|c|}{$\begin{array}{c}\text { Spina bifida } \\
\text { (total births } 498 \text { ) }\end{array}$} & \multicolumn{3}{|c|}{$\begin{array}{c}\text { Anencephaly } \\
\text { (total births 425) }\end{array}$} \\
\hline No. 31 & $M^{*}$ & $\mathbf{F}$ & No. 491 & $M^{*}$ & $F^{*}$ No. 755 \\
\hline $\begin{array}{l}\text { No. } 360 \\
\text { No visit } \\
\text { No. } 327\end{array}$ & $\begin{array}{l}F^{*} \\
F^{*} \mathrm{e} \\
F^{*}\end{array}$ & $\begin{array}{l}\mathbf{M} \\
\mathbf{M}\end{array}$ & $\begin{array}{l}\text { No. } 733 \\
\text { No. } 701 \\
\text { No. } 702\end{array}$ & $\begin{array}{l}M^{*} \\
F^{*} \\
F^{*} \\
F^{*}\end{array}$ & $\begin{array}{l}\text { M } \\
\text { Mnnd } \\
\text { Mnnd }\end{array}$ \\
\hline & & & $\begin{array}{l}\text { No. } 670 \\
\text { No. } 605 \\
\text { No. } 576 \\
\text { No. } 499 \\
\text { No. } 500\end{array}$ & $\begin{array}{l}F^{*} \\
F^{*} \\
F^{*} \\
F^{*} \\
F^{*}\end{array}$ & $\begin{array}{l}\text { F } \\
\text { F } \\
\text { Fsb } \\
\text { Fsb }\end{array}$ \\
\hline
\end{tabular}

$M$, male; $F$, female (italics indicate affected relative); *, index patient; $e$, encephalocele; sb, still born; nnd, neonatal death.

female twins of whom three were normal and two were still born but without malformation.

The proportion of twins born among the visited index patients, 13 in 870 is less, though not significantly so, than the approximately 1 in 50 expected in a random sample of the general population.

Sibs. The findings in the sibs do not differ appreciably between group 1 and 2 so the results in the two groups are combined and summarized in Table XI distinguishing spina bifida and anencephaly in index patients and distinguishing the sex of index patients and sibs. Only sibs for whom it wase possible to get documentary confirmation of the malformation are shown as affected, with two exceptions described below.

Spina Bifida Index Patients. Of 389 brothers, three had spina bifida and one a nasopharyngeal encephalocele which is entered in Table XI as 'spina bifida', and five anencephaly (including one iniencephaly). Of 341 sisters, nine had spina bifida and seven anencephaly including one still born girl (No. 364) with anencephaly born in Eire where the account given by the mother (who is a nurse) is accepted. Thus $2.31 \%$ of brothers and $4.69 \%$ of sisters and $3.42 \%$ of sibs of both sexes were affected with a neural tube malformation. Subdividing by sex of index patients shows no appreciable difference $(12 / 316=3 \cdot 80 \%$ for sibs of male and $13 / 414$ $=3.14 \%$ for sibs of female). The proportion affected of sibs born after the index patients (14/271 $=5 \cdot 17 \%$ ) was higher though not significantly so than of sibs born before the index patient $(11 / 459=$ $2.40 \%$ ).

Included among the index patients with spina bifida there were 11 male and 40 female patients with encephalocele. These had 82 sibs, of whom only one was affected (with anencephaly). 
TABLE XI

SIBS OF INDEX PATIENTS WITH SPINA BIFIDA (S) AND ANENCEPHALY (A) DISTINGUISHING THOSE BORN BEFORE AND AFTER THE INDEX PATIENTS

\begin{tabular}{|c|c|c|c|c|c|c|c|c|}
\hline \multirow[b]{2}{*}{ Index Patients } & \multicolumn{3}{|c|}{ Brothers } & \multicolumn{3}{|c|}{ Sisters } & \multirow[b]{2}{*}{$\begin{array}{l}\text { Grand Total } \\
\text { affected }\end{array}$} & \multirow[b]{2}{*}{ 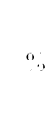 } \\
\hline & $\begin{array}{l}\text { Older (total } \\
\text { affected) }\end{array}$ & $\begin{array}{l}\text { Younger } \\
\text { (total } \\
\text { affected) }\end{array}$ & Total & $\begin{array}{l}\text { Older (total } \\
\text { affected) }\end{array}$ & $\begin{array}{l}\text { Younger } \\
\text { (total } \\
\text { affected) }\end{array}$ & Total & & \\
\hline $\begin{array}{l}\text { Spina bifida } \\
\text { Male }(n=217) \\
\text { Female }(n=261)\end{array}$ & $\begin{array}{l}108(2 S) \\
142(2 A)\end{array}$ & $\begin{array}{l}70(1 \mathrm{~S}, 2 \mathrm{~A}) \\
69(1 \mathrm{~S}, 1 \mathrm{~A})\end{array}$ & $\begin{array}{l}178(3 \mathrm{~S}, 2 \mathrm{~A}) \\
211(1 \mathrm{~S}, 3 \mathrm{~A})\end{array}$ & $\begin{array}{l}83(3 \mathrm{~S}) \\
126(3 \mathrm{~S}, 1 \mathrm{~A})\end{array}$ & $\begin{array}{l}55(2 \mathrm{~S}, 2 \mathrm{~A}) \\
77(1 \mathrm{~S}, 4 \mathrm{~A})\end{array}$ & $\begin{array}{l}138(5 S, 2 A) \\
203(4 S, 5 A)\end{array}$ & $\begin{array}{l}316(8 \mathrm{~S}, 4 \mathrm{~A}) \\
414(5 \mathrm{~S}, 8 \mathrm{~A})\end{array}$ & $\begin{array}{l}3 \cdot 80 \\
3 \cdot 14\end{array}$ \\
\hline Total $\quad(n=478)$ & $250(2 \mathrm{~S}, 2 \mathrm{~A})$ & $139(2 \mathrm{~S}, 3 \mathrm{~A})$ & $389(4 S, 5 A)$ & $209(6 \mathrm{~S}, 1 \mathrm{~A})$ & $132(3 \mathrm{~S}, 6 \mathrm{~A})$ & $341(9 \mathrm{~S}, 7 \mathrm{~A})$ & $730(13 S, 12 A)$ & $3 \cdot 42$ \\
\hline$\cdots$ & & & & & & & & \\
\hline $\begin{array}{l}\text { Anencephaly } \\
\text { Male }(\mathrm{n}=110) \\
\text { Female }(\mathrm{n}=282)\end{array}$ & $\begin{array}{c}67(2 \mathrm{~A}) \\
154(4 \mathrm{~S}, 5 \mathrm{~A})\end{array}$ & $\begin{array}{l}54 \\
127(4 \mathrm{~S}, 2 \mathrm{~A})\end{array}$ & $\begin{array}{l}121(2 \mathrm{~A}) \\
281(8 \mathrm{~S}, 7 \mathrm{~A})\end{array}$ & $\begin{array}{r}61(2 \mathrm{~S}, 1 \mathrm{~A}) \\
136(6 \mathrm{~S}, 7 \mathrm{~A})\end{array}$ & $\begin{array}{l}47(2 \mathrm{~A}) \\
108(1 \mathrm{~S}, 5 \mathrm{~A})\end{array}$ & $\begin{array}{l}108(2 \mathrm{~S}, 3 \mathrm{~A}) \\
244(7 \mathrm{~S}, 12 \mathrm{~A})\end{array}$ & $\begin{array}{l}229(2 \mathrm{~S}, 5 \mathrm{~A}) \\
525(15 \mathrm{~S}, 19 \mathrm{~A})\end{array}$ & $\begin{array}{l}3 \cdot 17 \\
6 \cdot 48\end{array}$ \\
\hline Total $(n=392)$ & $221(4 S, 7 A)$ & $181(4 \mathrm{~S}, 2 \mathrm{~A})$ & $402(8 S, 9 A)$ & $197(8 \mathrm{~S}, 8 \mathrm{~A})$ & $155(1 \mathrm{~S}, 7 \mathrm{~A})$ & $352(9 \mathrm{~S}, 15 \mathrm{~A})$ & $754(17 \mathrm{~S}, 24 \mathrm{~A})$ & $5 \cdot 44$ \\
\hline $\begin{array}{l}\text { Grand total } \\
\qquad(\mathrm{n}=870)\end{array}$ & $471(6 \mathrm{~S}, 9 \mathrm{~A})$ & $320(6 \mathrm{~S}, 5 \mathrm{~A})$ & $791(12 S, 14 A)$ & $406(14 S, 9 A)$ & $287(4 S, 13 A)$ & $693(18 S, 22 A)$ & $1484(30 \mathrm{~S}, 36 \mathrm{~A})$ & $4 \cdot 45$ \\
\hline
\end{tabular}

Anencephaly Index Patients. Of 402 brothers, eight had spina bifida and nine anencephaly. Of 352 sisters, nine had spina bifida and 15 anencephaly (including one unconfirmed still born girl [No. 660] born in India where the parents' story was accepted as reliable and one encephalocele). Thus, $4 \cdot 23 \%$ of brothers and $6.82 \%$ of sisters were affected and $5 \cdot 44^{\circ}$ o of sibs of both sexes were affected by neural tube malformations. In addition (and not shown in Table XI) two male abortuses, families Nos. 419 and 454 , had documented anencephaly. Subdividing by sex of index patient shows fewer sibs of male index patients affected than of female, $7 / 229=$ $3 \cdot 17 \%$ and $34 / 525=6 \cdot 48 \%$, respectively. The differences are not significant. The proportion of sibs born after the index patient $(14 / 336=4 \cdot 17 \%)$ was lower than that of sibs born before the index patient $(27 / 418=6 \cdot 46 \%)$; but again the difference is not significant.

Combining spina bifida and anencephalic index patients $4.45 \%$ of sibs were affected, including $4.33 \%$ of older and $4.65 \%$ of younger sibs.
Subdividing by father's occupation (Registrar General's social classes I-V) there are no significant differences in the proportion of sibs affected. Subdividing by mother's father's occupation there was a relatively low risk of recurrence when mother grew up in a social class I, II, or IIIa home and a high risk when mother's father's occupation was not known. This is shown in Table XII.

Subdividing by grandparental birthplaces, the proportion of sibs affected are shown in Table XIII for index patients where all four grandparents were from South-East England, Ireland, India with Pakistan, and the West Indies. There is no indication of any lower recurrence risk for couples both originating in South-East England or of a higher recurrence risk for those both of Irish origin.

The series presents little information on the effect of the proportion of sibs affected where there is another relative affected in the family. There were 12 children born after an index patient where the mother had another child with a neural tube malformation born before the index patient; one had

TABLE XII

PROPORTION OF SIBS AFFECTED BY FATHER'S SOCIAL CLASS AND BY MOTHER'S FATHER'S SOCIAL CLASS (GROUP 1 ONLY)

\begin{tabular}{|c|c|c|c|c|c|c|}
\hline \multirow{2}{*}{ Social Class } & \multicolumn{3}{|c|}{ Father's Social Class } & \multicolumn{3}{|c|}{ Mother's Father's Social Class } \\
\hline & Total & Affected* & Affected $\%$ & Total & Affected & Affected ${ }_{0}^{\circ}$ \\
\hline I, II, IIIa, and 0 & 366 & $8 \mathrm{~S} ; 10 \mathrm{~A}$ & $4 \cdot 92$ & 316 & $1 \mathrm{~S} ; 5 \mathrm{~A}$ & $1 \cdot 90$ \\
\hline IIIb & 710 & $12 S ; 18 A$ & $4 \cdot 22$ & 419 & $13 S ; 9 A$ & $5 \cdot 25$ \\
\hline IV, V & 404 & $10 S ; 8 A$ & $4 \cdot 46$ & 478 & $10 \mathrm{~S} ; 12 \mathrm{~A}$ & $4 \cdot 60$ \\
\hline Not known & 4 & 0 & 0.00 & $\overline{152}$ & $3 \mathrm{~S} ; 7 \mathrm{~A}$ & $6 \cdot 58$ \\
\hline Total & 1484 & $30 \mathrm{~S} ; 36 \mathrm{~A}$ & $4 \cdot 45$ & 1365 & $27 \mathrm{~S} ; 33 \mathrm{~A}$ & $4 \cdot 40$ \\
\hline
\end{tabular}

* $\mathrm{S}$, spina bifida; $\mathrm{A}$, anencephaly. 
TABLE XIII

PROPORTION OF SIBS AFFECTED BY BIRTH PLACE OF ALL FOUR GRANDPARENTS OF INDEX PATIENTS

\begin{tabular}{c|l|c|c}
\hline $\begin{array}{c}\text { No. of } \\
\text { Index } \\
\text { Patients }\end{array}$ & \multicolumn{1}{|c|}{$\begin{array}{c}\text { Grandparental } \\
\text { Birth Place }\end{array}$} & Sibs & $\begin{array}{c}\text { Proportion } \\
\text { Affected } \\
(\%)\end{array}$ \\
\hline 258 & South-East England & $\begin{array}{c}409 \\
(15 \mathrm{~S}, 8 \mathrm{~A})\end{array}$ & 5.62 \\
\hline 76 & Ireland & $\begin{array}{c}163 \\
(1 \mathrm{~S}, 5 \mathrm{~A})\end{array}$ & 3.68 \\
\hline 28 & India with Pakistan & $\begin{array}{c}75 \\
(1 \mathrm{~S}, 4 \mathrm{~A})\end{array}$ & 6.67 \\
\hline 20 & West Indies & 50 & 0.00 \\
\hline
\end{tabular}

anencephaly. There were also 11 children born after the mother had had another child with a neural tube malformation after the index patient; one had anencephaly. Where an aunt or uncle of an index patient had a neural tube malformation (eight families) one of six sibs had anencephaly. Where a cousin of the index patient ( 28 families) had a neural tube malformation, of 65 sibs one had spina bifida and one anencephaly; in seven of these 28 families, two cousins were affected but none of 13 sibs was affected.

TABLE XIV

SIBS AFFECTED WHEN ANOTHER RELATIVE AFFECTED

\begin{tabular}{l|c|c|c}
\hline & \multicolumn{3}{|c}{ Affected Relative } \\
\cline { 2 - 4 } & Sibs & Aunt/Uncle & Cousin \\
\hline No. of sibs & 23 & 5 & 65 \\
& $(2 \mathrm{~A})$ & $(1 \mathrm{~A})$ & $(1 \mathrm{~S}, 1 \mathrm{~A})$ \\
\hline
\end{tabular}

Sibs with Other Malformations. The sibs with malformations other than those of the neural tube are shown in Appendix III (p. 234). Among a total of 1484 sibs 31 had a major malformation. These include seven patients with congenital heart defects, four with congenital dislocation of the hip, three with pyloric stenosis, two with imperforate anus, one with cleft lip, one with cleft palate, two with talipes equinovarus, one with Hirschsprung's disease, two with Down's syndrome, one with acephalus and holocardius, one with Klippel Feil cervical vertebral malformation, examphalos and aortic atresia, one with a sacrococcygeal tumour, and two with hydrocephalus (both perforated before delivery) without spina bifida. Both the total number of malformations, other than neural tube malformations, and the individual malformations do not differ from those that might be found in any random series of births. Only the Klippel Feil anomaly, the sacrococcygeal tumour and, less plausibly, the acephalus and holocardius might be regarded as possibly related to spina bifida and anencephaly.

Parents. No parent had a meningocele or meningomyelocele. One mother (family 526) had a large mole over the lumbar spine and bilateral talipes, and another (family 293) had a hairy mole removed and was recorded as having spina bifida occulta.

Half Sibs. Of 74 maternal half sibs of spina bifida cases one had spina bifida and one anencephaly; of 42 paternal half sibs, one had spina bifida. For anencephaly cases there were 41 maternal half sibs of whom one had spina bifida and 42 paternal half sibs who were all unaffected. The details are summarized in Table XV. Of the 84 paternal half sibs one was affected and of the 115 maternal half sibs three $(2.61 \%)$ were affected. In sum, four of 199 , or $2.0 \%$, were affected.

\section{TABLE XV}

HALF SIBS OF INDEX PATIENTS SHOWING THOSE WHO HAVE SPINA BIFIDA (S) OR ANENCEPHALY (A)

\begin{tabular}{c|c|c|c|c}
\hline $\begin{array}{c}\text { Index Patient } \\
\text { with a Half Sib }\end{array}$ & \multicolumn{2}{|c|}{ Paternal } & \multicolumn{2}{c}{ Maternal } \\
\cline { 2 - 5 } & Brothers & Sisters & Brothers & Sisters \\
\hline $\begin{array}{c}\text { Spina bifida } \\
(\mathrm{n}=53)\end{array}$ & $\begin{array}{c}28 \\
(1 \mathrm{~S})\end{array}$ & 14 & 46 & $\begin{array}{c}28 \\
(1 \mathrm{~S}, 1 \mathrm{~A})\end{array}$ \\
\hline $\begin{array}{c}\text { Anencephaly } \\
(\mathrm{n}=33)\end{array}$ & 20 & 22 & 16 & $\begin{array}{c}25 \\
(1 \mathrm{~S})\end{array}$ \\
\hline Total (n=86) & $\begin{array}{c}48 \\
(1 \mathrm{~S})\end{array}$ & 36 & 62 & $\begin{array}{c}53 \\
(2 \mathrm{~S}, 1 \mathrm{~A})\end{array}$ \\
\hline
\end{tabular}

Cousins. Though the attempt was made to check the cause of death in all reported still births and infant deaths in cousins, information on the first cousins of index patients is inevitably less complete than for sibs as the information is supplied by the index patients' parents. A positive report that a cousin was affected was usually found to be correct, but the parents may well not know of all the stillborn children of their brothers and sisters and when they do they may not know the cause of the still birth. The information on cousins is summarized in Table XVI. The report that a cousin was affected was confirmed in all but three cases, all born in Ireland, two with a convincing history. In summary, 4.32 per 1000 cousins were found affected, the individual risks being $1.21,4.94,3.01$, and 6.77 per 1000 for the children of father's brothers, father's sisters, mother's brothers, and mother's sisters, respectively. Only in the latter group is the number affected (14) significantly more (8.72) than 
TABLE XVI

COUSINS OF INDEX PATIENTS, SHOWING THOSE HAVING SPINA BIFIDA OR ANENCEPHALY

\begin{tabular}{|c|c|c|c|c|c|c|c|c|c|}
\hline & \multicolumn{2}{|c|}{ Father's Brothers } & \multicolumn{2}{|c|}{ Father's Sisters } & \multicolumn{2}{|c|}{ Mother's Brothers } & \multicolumn{2}{|c|}{ Mother's Sisters } & \multirow{2}{*}{ Total } \\
\hline & Sons & Daughters & Sons & Daughters & Sons & Daughters & Sons & Daughters & \\
\hline Spina bifida & 440 (1S) & 412 & $518(2 S, 2 A)$ & $485(1 S, 3 A)$ & 487 & $433(2 S, 1 A)$ & $514(2 S, 2 A)$ & $495(3 S, 3 A)$ & $3784(11 \mathrm{~S}, 11 \mathrm{~A})$ \\
\hline Anencephaly & 418 & 389 (1S) & $544(1 S)$ & $479(1 S)$ & 381 & $358(2 S)$ & $581(1 \mathrm{~S}, 1 \mathrm{~A})$ & $479(1 \mathrm{~S}, 1 \mathrm{~A})$ & $3629(7 \mathrm{~S}, 2 \mathrm{~A})$ \\
\hline Total & $858(1 S)$ & $801(1 S)$ & $1062(3 \mathrm{~S}, 2 \mathrm{~A})$ & $964(2 S, 3 A)$ & 868 & $791(4 S, 1 A)$ & $1095(3 \mathrm{~S}, 3 \mathrm{~A})$ & $|974(4 \mathrm{~S}, 4 \mathrm{~A})|$ & $7413(18 S, 13 A)$ \\
\hline
\end{tabular}

\begin{tabular}{l|c|c|c|c}
\hline Grand total & $1659(2 \mathrm{~S})$ & $2026(5 \mathrm{~S}, 5 \mathrm{~A})$ & $1659(4 \mathrm{~S}, 1 \mathrm{~A})$ & $2069(7 \mathrm{~S}, 7 \mathrm{~A})$ \\
\hline Percentage & $1.21 \%$ & $4.94 \%$ & $3.01 \%$ & $6.77 \%$ \\
\hline
\end{tabular}

would be expected in a random sample of the same size from the general population.

\section{Discussion}

Birth Frequency. The birth frequency of both malformations shows the expected relatively low figure for South-East England. The birth frequency in South Wales (Carter et al, 1968) was approximately $2 \frac{1}{2}$ times higher for each malformation than in this London study. The comparison is shown in Table XVII.

TABLE XVII

BIRTH FREQUENCY OF SPINA BIFIDA AND ANENCEPHALY (PER 1000 BIRTHS). A COMPARISON OF GREATER LONDON AND SOUTH WALES

\begin{tabular}{l|c|c|c}
\hline & Spina Bifida & Anencephaly & Total \\
\hline \begin{tabular}{l|c} 
Greater London, 1965-68 \\
South Wales, 1956-62
\end{tabular} & $\begin{array}{c}1.54 \\
4.13\end{array}$ & $\begin{array}{c}1.41 \\
3.54\end{array}$ & $\begin{array}{l}2.95 \\
7.67\end{array}$ \\
\hline $\begin{array}{c}\text { Ratio (South Wales/ } \\
\text { Greater London) }\end{array}$ & 2.7 & 2.5 & 2.6 \\
\hline
\end{tabular}

A more recent series (1962-66) from South Wales (Richards and Lowe, 1971) gave frequencies of 3.9 and 3.1 for spina bifida and anencephaly, respectively. The South Wales frequency is exceeded perhaps only in Northern Ireland where Elwood (1972) reported 3.6 and 3.5 for the years 1964-68; the spina bifida figure in this series is probably an underestimate because of the classification of some cases as hydrocephalus. Liverpool with 3.4 and 3.1 in 1960-64 (Smithells, 1968) approaches the South Wales figures. Birmingham with 3.1 and 2.8 for 1955-59 (Leck et al, 1968), Glasgow with 2.80 and 2.83 (Wilson, 1970), and Southampton with 3.2 and 1.9 for 1958-62 (Williamson, 1965) have figures intermediate between those for South Wales and London.

These detailed surveys confirm the overall pic- ture of a cline of increasing frequency from SouthEast to North-West Britain shown by the Registrar General's anencephaly still-birth data (Carter, 1969). They also indicate that the frequency of spina bifida cystica (with or without hydrocephalus and including encephalocele) follows the same cline.

Season of Birth. Still-birth registration data have tended to show an excess of anencephaly among winter births. This was noted early in the Scottish data (Edwards, 1958) with peaks in December and January and also may be seen in the data for England and Wales since the introduction of the regisstration of the causes of still birth. Of the 10 calendar years 1961-70, the October rates were higher than the average for the year in 7 out of the 10 calendar years, for November in 9, for December in 9, for January in 9, and for February in 7. In contrast the rates were low in March, April, May, June, July, August, and September for 7, 6, 8, 9, 8, 7, and 8 out of the 10 calendar years, respectively. No comparable national data are available for spina bifida, but the data for Birmingham (Leck, 1972) agree with the present series in showing a relationship of the birth frequency with month of birth similar to that of anencephaly, if the anencephaly rates for one month are related to those for spina bifida one or two months later.

Maternal Age and Birth Order. A Ushaped relationship of birth order and maternal age was shown early in the Scottish registration data for anencephaly (Record, 1961). More recently the larger scale data for England and Wales have become available and the same relationship holds for the years 1962-66 (Carter, 1969); there is an excess of first born and late born, and an excess at maternal ages under 20 years and over 35 years. The relationship has persisted in the years 1967-70. The effects of birth order and maternal age cannot be separated for this data as published. However, 
independent $U$-shaped birth order and maternal age effects for anencephaly and spina bifida have been shown for Birmingham (Record and McKeown, 1949; Leck, 1972) and on a special tabulation of the Scottish anencephaly data (Record, 1961).

In the South Wales series approximate standardization (using a comparison with the births in England and Wales) for birth order left little late birth order effect, but a primiparity and early and late maternal age effect (Carter et al, 1969). In this London series the availability of a simultaneous tabulation for maternal age and birth order for Greater London (Registrar General, unpublished) makes accurate standardization possible and it is interesting (see Table VII) that in the present series there is again no excess (rather a deficit) among late births and also no significant excess among firstborn. Only a U-shaped maternal age effect remains with an excess among mothers under 20 and over 35 years. The excess for young mothers may in part be associated with social class since only five in 90 were in social class I and II, but there was no such association for mothers over the age of 35 years, of whom 12 in 97 were in classes I and II.

Parental Birth Places. It is of considerable interest to know whether the marked ethnic differences in birth frequency of central nervous system malformations persist after migration. Leck (1969) has demonstrated that in Birmingham the birth frequency of spina bifida and anencephaly for mothers of different ethnic origin parallels that in the countries of origin, the descending order of frequency being Ireland, India, England, and the West Indies. He (Leck, 1972) notes that the birth frequency in Negroes tends to be low in a wide variety of environments, England, South Africa, and North America. In contrast the frequency for the Irish tends to be high in Birmingham and Boston, though not so high as in Northern Ireland. The findings in this study (see Tables IX and XIII) though less direct than those from Birmingham again suggest a descending order of birth frequency for those born in Ireland, India and Pakistan, North-West Britain, South-East England, and the West Indies. The low frequency in those from the West Indies is the more remarkable because most of the fathers are manual workers and thus in social classes IIIb, IV, and V.

\section{Relatives.}

Twins. The smaller proportion than expected of twin-born in the London series was also seen in the
South Wales series where there were 13 twin-born among 784 index patients. Such a deficit has been seen in most, though not all, other reported series (listed in Czeizel and Révész, 1970). If a real phenomenon, this deficit may be associated with the small proportion affected of co-twins of patients with spina bifida and anencephaly. Both malformations probably occur at a higher frequency early in pregnancy than in live and still births and therefore both probably predispose to abortion. A twin pregnancy in which both fetuses were affected might be expected to have a still higher risk of abortion.

Sibs with Neural Tube Malformations. The proportion of sibs found affected is in good agreement with that found in other studies. The South Wales findings were compared with those of earlier surveys (Carter et al, 1968), and this London series is compared with the South Wales and a recently reported series from Glasgow (Richards, McIntosh, and Sweenie, 1972) in Table XVIII. The latter series is comparable though substantially fewer families were traced. The proportion of sibs affected is actually higher, though not significantly so, in the Glasgow than the South Wales series, but the London series shows a lower proportion affected, as might be expected from the lower birth frequency in London, though again the difference is not significant.

The London series shows a higher proportion of affected sibs of anencephalic than of spina bifids index patients. This difference is not significant and in the other two series the difference is reversed. There is no real indication of a difference in the proportion of sibs affected according to whether the index patient had spina bifida or anencephaly.

There is a consistent, though not very strong, tendency in all three series for an affected sib to have the same type of malformation as the index patient. This is shown in Table XIX. This tendency is most marked in the Glasgow series.

The absence of any increase in malformations other than those of the spina bifida-anencephaly group in the sibs is consistent with the findings in other series, including the South Wales and Glasgow series. In earlier studies (for example, Record and McKeown, 1949) it was considered that hydrocephalus was aetiologically related to spina bifida and anencephaly. This however was probably due to the classification of cases of hydrocephalus secondary to spina bifida as hydrocephalus. One example of hydrocephalus was recorded as occurring among the sibs in the South Wales study, none in the Glasgow survey and only two in this study.

Half Sibs. It is unfortunate that so few half 
TABLE XVIII

PROPORTION OF SIBS AFFECTED IN THREE LARGE RECENT FAMILY STUDIES WITH A COMPARISON WITH THE PROPORTION AFFECTED IN THE GENERAL POPULATION

\begin{tabular}{|c|c|c|c|c|}
\hline & $\begin{array}{c}\text { Malformation } \\
\text { in Population }(\%)\end{array}$ & $\begin{array}{l}\text { Proportion of Sibs } \\
\text { Malformed }\end{array}$ & $\begin{array}{l}\text { Malformations } \\
\text { in Sibs }(\%)\end{array}$ & $\begin{array}{l}\text { Relative Proportion } \\
\text { Sibs/Population }\end{array}$ \\
\hline $\begin{array}{l}\text { South Wales } \\
\text { Spina bifida } \\
\text { Anencephaly }\end{array}$ & $\begin{array}{l}0 \cdot 413 \\
0 \cdot 354\end{array}$ & $\begin{array}{l}52 / 854 \\
29 / 709\end{array}$ & $\left.\begin{array}{l}6 \cdot 09 \\
4 \cdot 10\end{array}\right\} 5 \cdot 18 \pm 0.56$ & $\times 6.8$ \\
\hline $\begin{array}{l}\text { Glasgow } \\
\text { Spina bifida } \\
\text { Anencephaly }\end{array}$ & $\begin{array}{l}0 \cdot 280 \\
0 \cdot 283\end{array}$ & $\begin{array}{l}25 / 450 \\
26 / 454\end{array}$ & $\left.\begin{array}{l}5.56 \\
5.73\end{array}\right\} 5.64 \pm 0.85$ & $\times 10.1$ \\
\hline $\begin{array}{l}\text { London } \\
\text { Spina bifida } \\
\text { Anencephaly }\end{array}$ & $\begin{array}{l}0 \cdot 154 \\
0 \cdot 141\end{array}$ & $\begin{array}{l}25 / 730 \\
41 / 754\end{array}$ & $\left.\begin{array}{l}3.42 \\
5.44\end{array}\right\} 4.45 \pm 0.54$ & $\times 15 \cdot 8$ \\
\hline
\end{tabular}

TABLE XIX

TENDENCY FOR AFFECTED SIBS TO HAVE THE SAME MALFORMATION AS THE INDEX PATIENT

\begin{tabular}{l|c|c|c}
\hline \multirow{2}{*}{ Index Patient } & \multicolumn{2}{|c|}{ Sib } & Same : Different \\
\cline { 2 - 4 } & Spina Bifida & Anencephaly & \\
\hline South Wales & 32 & 20 & $48: 33$ \\
Spina bifida & 13 & 16 & \\
Anencephaly & 14 & 5 & $24: 11$ \\
\hline Glasgow & 6 & 10 & \\
Spina bifida & 13 & 12 & $37: 29$ \\
Anencephaly & 17 & 24 & \\
\hline London & & & \\
Spina bifida & & & \\
Anencephaly & &
\end{tabular}

sibs were found in either South Wales or the London survey, since the comparison of the proportion affected of maternal and paternal half sibs would be a valuable pointer as to whether the father's genotype contributes to the risk of his children having spina bifida or anencephaly. A larger series of half sibs would be valuable, though the point may be clarified first from information on the proportion affected of children of male and female patients.

Cousins. As in the South Wales and other series, only among the mother's sisters' children is the proportion with affected spina bifida and anencephaly greater than in the general population. The most likely explanation is that information is most complete for this class of cousins.

Social Class. The importance of social class was shown clearly in the Scottish registration data (Edwards, 1958). It was strikingly confirmed in the national sample reported by Butler and Alberman (1969). The effect was less marked but still present in more local surveys in Birmingham (Leck, 1972), South Wales (Laurence et al, 1968b), and in this present London survey.
Genetics. The findings in this family survey, as in earlier surveys, are suggestive of a multifactorial aetiology for spina bifida and anencephaly, with a genetic predisposition depending on variation at several gene loci and additional environmental factors. However, much further study is needed to prove this and to identify the mechanism. There are no indications of any single gene-determined component among this group of malformations. The proportion of sibs affected is not increased where there is parental consanguinity, nor is it increased where a relative other than a sib is affected (though there is no information yet on the risk where the parent is also affected).

Assuming polygenic inheritance, the ratio of proportion of sibs affected to birth frequency in South Wales and London is much as expected. The heritability estimates, using Falconer's method $(1965 / 66)$ on the relative proportions affected of sibs of patients and of the general population, are about 60,65 , and $70 \%$ for the South Wales, Glasgow, and London series, respectively. This estimate of heritability includes common family environment. If, however, the proportion of mother's sister's children affected is representative of all cousins, this group with a lesser degree of common family environment gives a similar estimate of heritability. It should be remembered however that this estimate of heritability refers to the proportion of variance within the community studied, for example South Wales or London, which is due to genetic variance, and that $100 \%$ heritability within each community is compatible with all the difference in the frequency between South Wales and London being environmental. It is however difficult to visualize other than a genetic basis for the low incidence of neural tube malformations among Negroes in a wide variety of environments.

We are much indebted to Miss B. Spain of the Greater 
London Council for her collaboration throughout the study. We gratefully acknowledge the help of the Association of London Borough Medical Officers of Health and the staffs of their departments; the staffs of the maternity hospitals in Greater London who gave us an introduction to controls; $\mathrm{Mr} \mathrm{D}$. Smale and the staff at the National Health Service Central Register at Southport; and particularly Miss P. K. Heath and Mrs A. V. Hickman who shared the family visiting of the main series with K.A.E. The Department of Health and Social Security generously paid for the copies of the death and still-birth certificates.

\section{REFERENCES}

Butler, N. R. and Alberman, E. D. (eds.) (1969). Perinatal Problems. (The Second Report of the 1958 British Perinatal Mortality Survey.) Churchill Livingstone, Edinburgh.

Carter, C. O. (1969). Spina bifida and anencephaly: a problem in genetic-environmental interaction. Fournal of Biosocial Science, 1, 71-83.

Carter, C. O., David, P. A., and Laurence, K. M. (1968). A family study of major central nervous system malformations in South Wales. Fournal of Medical Genetics, 5, 81-106.

Czeizel, A. and Révész, C. (1970). Major malformations of the central nervous system in Hungary. British fournal of Preventive and Social Medicine, 24, 205-222.

Edwards, J. H. (1958). Congenital malformations of the central nervous system in Scotland. British fournal of Preventive and Social Medicine, 12, 115-130.

Elwood, J. H. (1970a). Anencephalus in the British Isles. Developmental Medicine and Child Neurology, 12, 582-591.

Elwood, J. H. (1970b). Notification of congenital malformations in Northern Ireland 1964-66. Medical Officer, 123, 33-36.

Elwood, J. H. (1972). Major central nervous system malformations notified in Northern Ireland (1964-1968). Developmental Medicine and Child Neurology, 14, 731-739.
Falconer, D. S. (1965/66). The inheritance of liability to certain diseases, estimated from the incidence among relatives. Annals of Human Genetics, 29, 51-76.

Laurence, K. M., Carter, C. O., and David, P. A. (1968a). Major central nervous system malformations in South Wales. I. Incidence, local variations and geographical factors. British fournal of Preventive and Social Medicine, 22, 146-160.

Laurence, K. M., Carter, C. O., and David, P. A. (1968b). Major central nervous system malformations in South Wales. II. Pregnancy factors, seasonal variation, and social class effects. British Fournal of Preventive and Social Medicine, 22, 212-222.

Leck, I. (1969). Ethnic differences in the incidence of malformations following migration. British fournal of Preventive and Social Medicine, 23, 166-173.

Leck, I. (1972). The etiology of human malformations: insights from epidemiology. Teratology, 5, 303-314.

Leck, I., Record, R. G., McKeown, T., and Edwards, J. H. (1968). The incidence of malformations in Birmingham. Teratology, 1 , 263-279.

Record, R. G. (1961). Anencephalics in Scotland. British fournal of Preventive and Social Medicine, 15, 93-105.

Record, R. G. and McKeown, T. (1949). Congenital malformations of the central nervous system. 1. A survey of 930 cases. British Fournal of Preventive and Social Medicine, 3, 183-219.

Richards, I. D. G. and Lowe, C. R. (1971). Incidence of congenital defects in South Wales 1964-6. British fournal of Preventive and Social Medicine, 25, 59-64.

Richards, I. D. G., McIntosh, H. T., and Sweenie, S. (1972). A genetic study of anencephaly and spina bifida in Glasgow. Developmental Medicine and Child Neurology, 14, 626-639.

Smithells, R. W. (1968). Incidence of congenital abnormalities in Liverpool, 1960-64. British fournal of Preventive and Social Medicine, 22, 36-37.

Weatherall, J. A. C. (1969). A notification of congenital malformaMedical Officer, 121, no. 6, 65-68.

Williamson, E. H. (1965). Incidence and family aggregation of major congenital malformations of central nervous system. fournal of Medical Genetics, 2, 161-172.

Wilson, T.S. (1970). Congenital malformations of the central nervous system among Glasgow births 1964-68. Health Bulletin, 28, $32-38$.

\section{Appendix I}

\section{Main Series}

M, male; F, female; *, index patient; italics indicate affected relative; [ ], twins; sb, stillbirth; A, anencephalus;

$S$, spina bifida; e, encephalocele.

\begin{tabular}{|c|c|c|c|c|c|}
\hline \multirow{2}{*}{$\begin{array}{l}\text { Serial } \\
\text { No. }\end{array}$} & \multirow{2}{*}{ Sibship } & \multicolumn{2}{|c|}{ Half Sibs } & \multicolumn{2}{|c|}{ Date of Birth } \\
\hline & & Paternal & Maternal & Father & Mother \\
\hline \multicolumn{6}{|c|}{$\begin{array}{l}\text { SPINA BIFIDA-MALES } \\
\text { One-child families }\end{array}$} \\
\hline $\begin{array}{r}3 \\
6 \\
22 \\
24 \\
27 \\
28 \\
31 \\
36 \\
46 \\
58 \\
59 \\
64 \\
65 \\
69 \\
72 \\
88 \\
95 \\
101 \\
102 \\
108 \\
112 \\
119\end{array}$ & $\begin{array}{l}M^{*} 4 / 65 \\
M^{*} 4 / 65 \\
M^{*} 8 / 65 \\
M^{*} \mathrm{e} 8 / 65 \\
M^{*} 8 / 65 \\
M^{*} 965 \\
{\left[M^{*} 9 / 65 ; \mathrm{F} 9 / 65\right]} \\
M^{*} 10 / 65 \\
M^{*} 12 / 65 \\
M^{*} 2 / 66 \\
M^{*} 2 / 66 \\
M^{*} 2 / 66 \\
M^{*} 2 / 66 \\
M^{*} 3 / 66 \\
M^{*} 3 / 66 \\
M^{*} 6 / 66 \\
M^{*} 8 / 66 \\
M^{*} 9 / 66 \\
M^{*} 9 / 66 \\
M^{*} 9 / 66 \\
M^{*} 10 / 66 \\
M^{*} 12 / 66\end{array}$ & $M-/ 52 ; M(S) 7 / 53$ & $\begin{array}{l}\text { M } 12 / 61 \\
M 1 / 67 ; \text { F } 8 / 68 \\
\text { F } 10 / 67 ; F 12 / 68 \\
\text { M } 2 / 48 ; \text { F } 12 / 51 \\
M 10 / 68 \\
F(A) 1 / 69 \\
\text { F } 5 / 49 ; \text { F } 8 / 50 \\
\text { F } 9 / 51 ; M 11 / 56 \\
\text { F } 11 / 59 ; M 6 / 63 \\
F(S) 9 / 64\end{array}$ & $\begin{array}{r}-1 / 30 \\
2 / 35 \\
3 / 28 \\
9 / 26 \\
-140 \\
4 / 40 \\
4 / 41 \\
11 / 40 \\
-136 \\
-142 \\
8 / 46 \\
9 / 20 \\
6 / 45 \\
6 / 38 \\
4 / 35 \\
12 / 15 \\
\text { NK } \\
6 / 40 \\
-139 \\
9 / 42 \\
-142 \\
-138\end{array}$ & $\begin{array}{r}1 / 41 \\
9 / 36 \\
11 / 29 \\
5 / 31 \\
6 / 48 \\
8 / 40 \\
12 / 43 \\
4 / 41 \\
3 / 32 \\
10 / 41 \\
7 / 44 \\
3 / 33 \\
5 / 44 \\
5 / 38 \\
11 / 37 \\
5 / 23 \\
9 / 42 \\
1 / 45 \\
9 / 43 \\
12 / 43 \\
10 / 44 \\
1 / 28\end{array}$ \\
\hline
\end{tabular}

$M$ 11/59; M 6/63 
Appendix I Continued

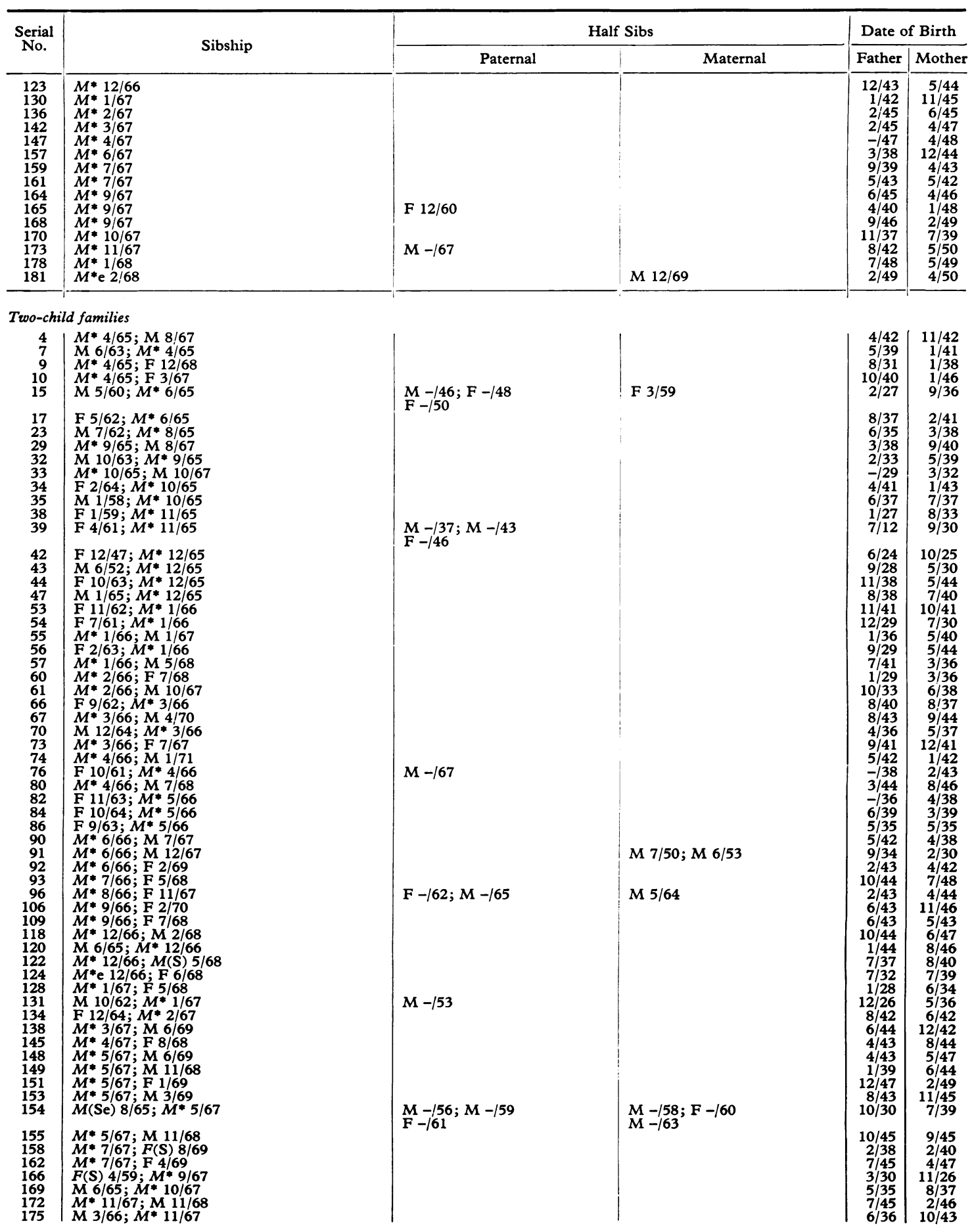


Appendix I Continued

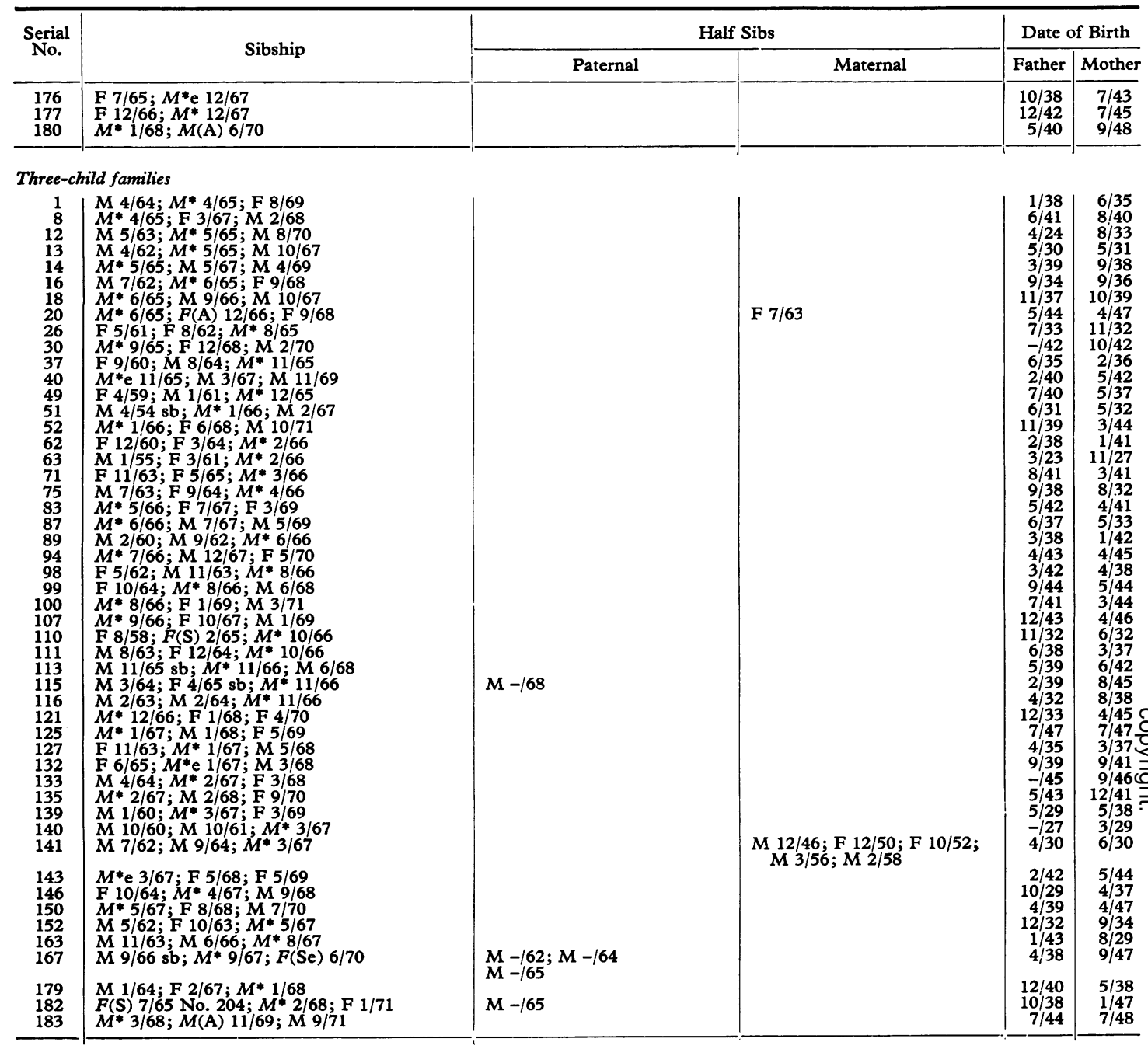

Four-child families

\begin{tabular}{|c|c|c|c|c|}
\hline $\begin{array}{r}5 \\
11 \\
19 \\
21 \\
41 \\
45 \\
50 \\
81 \\
85 \\
97 \\
105 \\
126 \\
129 \\
137 \\
156 \\
184\end{array}$ & 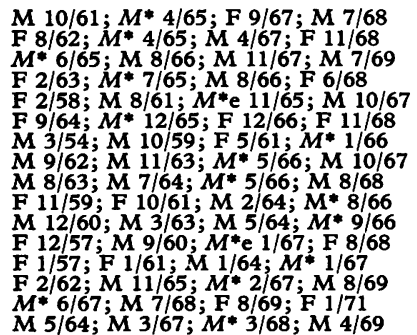 & M -/52; F NK; F NK & $\begin{array}{r}10 / 37 \\
12 / 39 \\
2 / 39 \\
3 / 40 \\
9 / 34 \\
4 / 37 \\
10 / 28 \\
1 / 31 \\
3 / 38 \\
2 / 31 \\
9 / 39 \\
8 / 32 \\
3 / 21 \\
-1 / 35 \\
7 / 46 \\
3 / 43\end{array}$ & $\begin{array}{r}1 / 42 \\
10 / 44 \\
8 / 40 \\
2 / 43 \\
11 / 35 \\
4 / 37 \\
8 / 31 \\
6 / 43 \\
11 / 41 \\
9 / 40 \\
1 / 40 \\
7 / 39 \\
11 / 28 \\
7 / 38 \\
3 / 49 \\
10 / 46\end{array}$ \\
\hline
\end{tabular}

Five-child families

$2 \mid M 2 / 61 ; M 3 / 63 ; M^{*} 4 / 65 ; F(A) 7 / 66$ No. $619 ; M$ 5/68

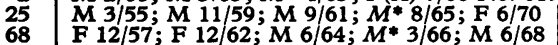


Appendix I Continued

\begin{tabular}{|c|c|c|c|c|c|}
\hline \multirow{2}{*}{$\begin{array}{c}\text { Serial } \\
\text { No. }\end{array}$} & \multirow{2}{*}{ Sibship } & \multicolumn{2}{|c|}{ Half Sibs } & \multicolumn{2}{|c|}{ Date of Birth } \\
\hline & & Paternal & Maternal & Father & Mother \\
\hline $\begin{array}{r}77 \\
78 \\
144 \\
160 \\
171 \\
174\end{array}$ & 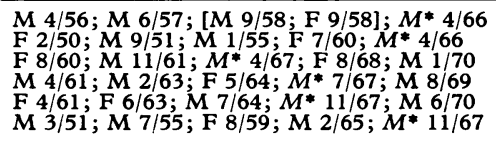 & & $\begin{array}{l}M 11 / 46 ; M 9 / 53 \\
M 9 / 44 ; M 12 / 45 ; M 8 / 48\end{array}$ & $\begin{array}{r}4 / 23 \\
3 / 17 \\
2 / 29 \\
2 / 41 \\
12 / 35 \\
\text { NK }\end{array}$ & $\begin{array}{r}12 / 24 \\
2 / 23 \\
5 / 32 \\
10 / 43 \\
1 / 32 \\
6 / 29\end{array}$ \\
\hline \multicolumn{6}{|c|}{ Six-child families } \\
\hline $\begin{array}{l}48 \\
79\end{array}$ & $\begin{array}{l}\text { F } 6 / 48 ; M 12 / 52 ; \text { F } 3 / 54 ; \text { F } 3 / 58 ; M 1 / 60 ; \\
M^{*} 12 / 65 \\
\text { F } 2 / 56 ; M 6 / 57 ; M 7 / 58 ; \text { F } 11 / 59 ; M^{*} 4 / 66 ; \\
\text { F } 9 / 68\end{array}$ & & & $\begin{array}{r}9 / 28 \\
10 / 33\end{array}$ & $\begin{array}{l}9 / 26 \\
1 / 35\end{array}$ \\
\hline 103 & $\begin{array}{l}\mathrm{M} 8 / 47 ; \mathrm{F} 7 / 51 ; \mathrm{F} 12 / 53 ; \mathrm{M} 12 / 55 ; \mathrm{M} 7 / 58 ; \\
M^{*} 9 / 66\end{array}$ & & & $4 / 16$ & $8 / 24$ \\
\hline 104 & $\begin{array}{l}\mathrm{M} 12 / 61 ; M 5 / 63 ; \mathrm{F} 9 / 64 ; M^{*} 9 / 66 ; \\
{[M 10 / 68 ; M 10 / 68]}\end{array}$ & $F-/ 54$ & & & \\
\hline 114 & $\begin{array}{l}M 10 / 53 ; M 9 / 55 \text { sb; F } 12 / 56 ; M 8 / 64 ; \\
M^{*} 11 / 66 ; M 3 / 69\end{array}$ & & & $5 / 31$ & $3 / 34$ \\
\hline
\end{tabular}

Seven-child families

$117 \mid$ M 6/54; M 7/59; M 11/60; M 10/61; F $3 / 63 ; M 3 / 65 ; M^{*} 11 / 66$

$-/ 16 \mid-130$

SPINA BIFIDA-FEMALES

One-child families

$185 \mid F^{*} 4 / 65$

195

$203 \quad F * 7 / 65$

$206 \quad F^{*} \mathrm{e} 7 / 65$

$229 \quad F^{*} 11 / 65$

$238 \quad F^{*} 12 / 65$

$255 \quad F^{* 2 / 66}$

$265 \quad F * 3 / 66$

$268 \quad F * 4 / 66$

$274 \quad F * 5 / 66$

$F^{*}$ 5/66

$277 \quad F * 5 / 66$

$281 \quad F * 5 / 66$

$284 \quad F * 6 / 66$

$292 \quad F * 7 / 66$

$297 \quad F * 9 / 66$

$298 \quad F^{*}$ e $9 / 66$

$306 \quad F^{*} 11 / 66$

$315 \quad F * 12 / 66$

$316 \quad F^{*} 1 / 67$

$343 \quad F * 4 / 67$

$346 \quad F * 5 / 67$

$348 \quad F^{*}$ e 5/67

$349 \quad F^{*} 6 / 67$

$351 \quad F^{*} 6 / 67$

$358 \quad F * 8 / 67$

$363 \quad F * 10 / 67$

$373 \quad F * 10 / 67$

$376 \quad F * \mathrm{e} 12 / 67$

378 F* $12 / 67$

$383 \mid F^{*} 1 / 68$

391

$F * 1 / 68$
$F * 2 / 68$

M 11/68; M 10/69

$\mathrm{M}-/ 45 ; \mathrm{F}-/ 49 ; \mathrm{F}-/ 53$

M $12 / 68$

F 1/63

F 9/51; M 6/53; F 10/55; M $8 / 63$

M NK

F NK; F NK; M NK; M NK

F 4/70

M 9/66; F 10/67

M 11/51

F $8 / 46 ; M-/ 51$

Two-child families

$190 \mid F^{*} 5 / 65 ;$ F 6/67

$194 M 9 / 62 ; F^{*} 5 / 65$

199 F $11 / 59 ; F^{*} 6 / 65$

$200 \quad F^{*} 6 / 65 ; M 1 / 67$

$F^{*} 6 / 65 ; \mathrm{F} 3 / 69$

$F * 7 / 65 ; M ~ 2 / 67$

$F^{*} 7 / 65 ; M 4 / 67$

F $12 / 63 ; F *$ e $8 / 65$

$F * 8 / 65 ; M 2 / 68$

F $3 / 63 ; F *$ e $9 / 65$

F 3/63;F*e 9/65

$F * 9 / 65 ; M 2 / 67$

$F^{*} 10 / 65 ; F(A) 10 / 6$

$F^{*} 11 / 65 ;$ F $5 / 68$
$F^{*} 11 / 65 ;$ F $6 / 67$
F -/51 sb; [M -/53; M -/53]

\begin{tabular}{c}
$6 / 42$ \\
$-/ 37$ \\
$7 / 23$ \\
$-/ 39$ \\
$-/ 27$ \\
$10 / 18$ \\
$3 / 35$ \\
$10 / 39$ \\
$8 / 3$ \\
$9 / 3$ \\
$9 / 09$ \\
$5 / 46$ \\
$6 / 32$ \\
$12 / 4$ \\
$4 / 4$ \\
$12 / 39$ \\
$10 / 40$ \\
$10 / 33$ \\
$4 / 42$ \\
$9 / 38$ \\
$-/ 45$ \\
-134 \\
\\
$N K$ \\
$12 / 37$ \\
$3 / 38$ \\
$-/ 46$ \\
$10 / 45$ \\
$9 / 24$ \\
$8 / 40$ \\
-144 \\
$7 / 40$ \\
$2 / 37$ \\
$6 / 29$ \\
$-/ 29$ \\
$N K$ \\
\hline
\end{tabular}

$3 / 45$
$5 / 38$

$4 / 44$
$11 / 46$

$11 / 46$
$6 / 38$

$2 / 28$

$8 / 44$

$4 / 39$

$4 / 34$

7/25

$7 / 25$

$4 / 47$

$8 / 33$
$7 / 45$

$4 / 48$

$4 / 45$

$3 / 44$

$8 / 31$

$1 / 48$

$8 / 44$

$5 / 44$ 
Appendix I Continued

\begin{tabular}{|c|c|c|c|c|c|}
\hline \multirow{2}{*}{$\begin{array}{c}\text { Serial } \\
\text { No. }\end{array}$} & \multirow{2}{*}{ Sibship } & \multicolumn{2}{|c|}{ Half Sibs } & \multicolumn{2}{|c|}{ Date of Birth } \\
\hline & & Paternal & Maternal & Father & Mother \\
\hline $\begin{array}{l}232 \\
236 \\
237 \\
247 \\
249 \\
250 \\
251 \\
252 \\
258 \\
259 \\
262 \\
267 \\
269 \\
273 \\
279 \\
282 \\
283 \\
299 \\
300 \\
303 \\
304 \\
305 \\
307 \\
308 \\
314 \\
317 \\
318 \\
319 \\
321 \\
322 \\
323 \\
326 \\
327 \\
330 \\
334 \\
335 \\
337 \\
338 \\
340 \\
341 \\
342 \\
353 \\
359 \\
360 \\
361 \\
366 \\
369 \\
370 \\
371 \\
374 \\
375 \\
380 \\
381 \\
382 \\
388 \\
389\end{array}$ & 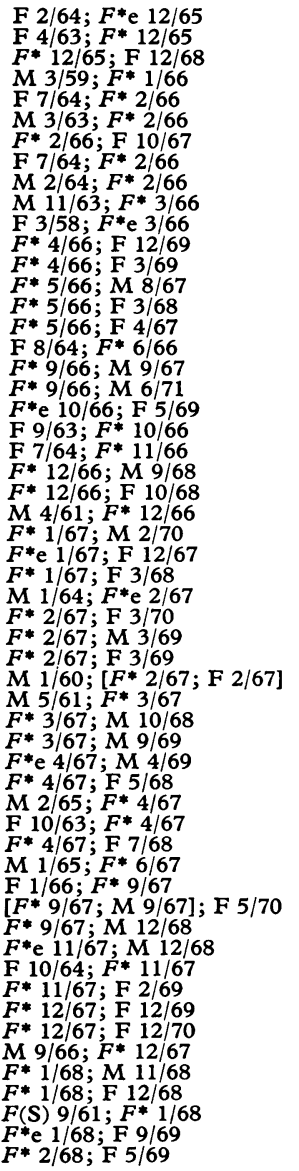 & & $\begin{array}{l}\text { F } 3 / 52 \mathrm{sb} ; \mathrm{M} 8 / 57 ; \mathrm{F} 11 / 58 \\
\text { M } 4 / 65\end{array}$ & 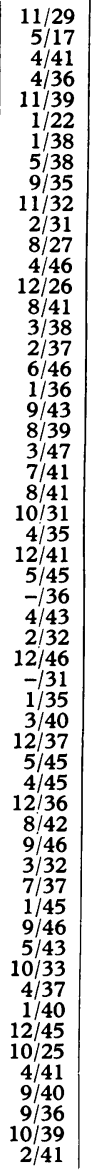 & $\begin{array}{r}11 / 43 \\
6 / 33 \\
4 / 43 \\
7 / 39 \\
1 / 37 \\
10 / 32 \\
4 / 41 \\
6 / 40 \\
3 / 38 \\
5 / 44 \\
6 / 36 \\
4 / 28 \\
7 / 45 \\
1 / 35 \\
11 / 45 \\
1 / 45 \\
7 / 37 \\
4 / 48 \\
5 / 40 \\
9 / 46 \\
4 / 40 \\
8 / 47 \\
5 / 42 \\
1 / 41 \\
8 / 27 \\
10 / 40 \\
3 / 43 \\
10 / 47 \\
11 / 38 \\
11 / 42 \\
9 / 41 \\
6 / 48 \\
11 / 33 \\
8 / 41 \\
5 / 39 \\
6 / 39 \\
12 / 46 \\
5 / 46 \\
10 / 41 \\
1 / 47 \\
3 / 49 \\
3 / 31 \\
8 / 32 \\
5 / 49 \\
9 / 48 \\
6 / 46 \\
4 / 39 \\
3 / 42 \\
2 / 46 \\
5 / 47 \\
-/ 28 \\
6 / 46 \\
12 / 45 \\
7 / 40 \\
9 / 44 \\
6 / 46 \\
\end{array}$ \\
\hline
\end{tabular}

Three-child families

186 F 7/49; M 9/55; F* 4/65

M $6 / 63 ; F^{*} 4 / 65 ; F(S) 5 / 66$ No. 278

$F^{*} 5 / 65 ; \mathrm{F} \mathrm{3/66;} \mathrm{F} 4 / 68$

M $5 / 62 ; F^{*} 5 / 65 ; M 12 / 67$

$M 5 / 62 ; F^{*} 5 / 65 ; M$
$F^{*}$ e $6 / 65 ; \mathrm{F} 8 / 66 ; M ~ 10 / 67$

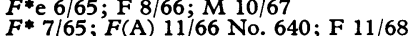

$F^{*} 7 / 65 ; M(\mathrm{~S}) 2 / 68$ No. $182 ; \mathrm{F} 1 / 71$

$M 10 / 60 ; M 10 / 62 ; F^{*} 8 / 65$

$M$ 5/61; F $2 / 63 ; F^{*} 8 / 65$

$F^{*} 8 / 65 ; \mathrm{F} 1 / 67 ; \mathrm{M}$ 7/69

M $4 / 64 ; F^{*} 8 / 65 ; M 7 / 67$

$M 11 / 63 ; F^{*} 10 / 65 ; F^{*} 8 / 70$

F $10 / 62 ; \mathrm{F} 12 / 64 ; F^{*} 11 / 65$

$F^{*} 11 / 65 ; M 3 / 67 ; M 4 / 70$

$F^{*} 11 / 65 ; M$ 6/67; M 8/69

F $6 / 62 ; M 11 / 64 ; F^{*} 12 / 65$

F $6 / 62 ; M 11 / 64 ; F^{*} 12 / 65$

F $7 / 48 ; F 5 / 53 ; F^{*} 12 / 65$
$F^{*} 12 / 65 ; M(A) 12 / 67 ; F($ A) $4 / 69$

F $1 / 63 ; F^{*} 1 / 66 ; F^{*} 7 / 68$

F $4 / 65 ; F * 1 / 66 ; M 1 / 68$

F $9 / 64 ; F^{*} 2 / 66 ; M$ 3/68

$F^{*} 2 / 66 ; M 10 / 67 ; M 3 / 69$

$F^{*}$ e $3 / 66 ; M$ 6/67; F 7/68

F $11 / 63 ; F^{*}$ e $3 / 66 ;$ F $8 / 67$ 
Appendix I Continued

\begin{tabular}{|c|c|c|c|c|c|}
\hline \multirow{2}{*}{$\begin{array}{c}\text { Serial } \\
\text { No. }\end{array}$} & \multirow{2}{*}{ Sibship } & \multicolumn{2}{|c|}{ Half Sibs } & \multicolumn{2}{|c|}{ Date of Birth } \\
\hline & & Paternal & Maternal & Father & Mother \\
\hline $\begin{array}{l}264 \\
266 \\
270 \\
272 \\
276 \\
278 \\
280 \\
285 \\
287 \\
288 \\
290 \\
291 \\
293 \\
301 \\
302 \\
309 \\
311 \\
320 \\
324 \\
325 \\
328 \\
329 \\
331 \\
332 \\
333 \\
339 \\
344 \\
352 \\
355 \\
362 \\
367 \\
377 \\
384 \\
387 \\
390 \\
392 \\
393\end{array}$ & 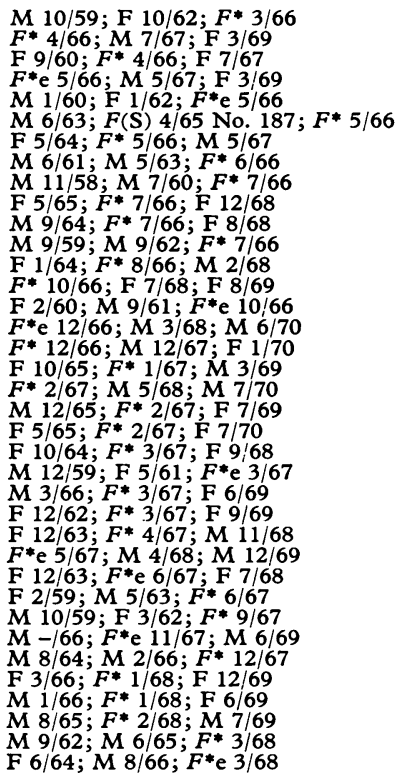 & & F $1 / 63 ; M 2 / 64$ & $\begin{array}{r}7 / 33 \\
6 / 35 \\
6 / 40 \\
1 / 44 \\
7 / 37 \\
12 / 40 \\
-1 / 37 \\
1 / 39 \\
-/ 18 \\
4 / 43 \\
7 / 35 \\
11 / 32 \\
7 / 40 \\
3 / 43 \\
1 / 37 \\
2 / 44 \\
11 / 42 \\
1 / 44 \\
2 / 43 \\
6 / 44 \\
4 / 32 \\
11 / 42 \\
9 / 32 \\
8 / 42 \\
9 / 33 \\
5 / 32 \\
6 / 25 \\
7 / 39 \\
1 / 32 \\
2 / 29 \\
-/ 46 \\
3 / 37 \\
2 / 37 \\
9 / 43 \\
8 / 30 \\
-1 / 35 \\
5 / 45\end{array}$ & $\begin{array}{r}7 / 36 \\
9 / 35 \\
1 / 44 \\
6 / 45 \\
9 / 38 \\
4 / 44 \\
2 / 35 \\
5 / 35 \\
8 / 35 \\
7 / 42 \\
12 / 33 \\
5 / 34 \\
2 / 40 \\
11 / 41 \\
2 / 39 \\
3 / 48 \\
2 / 46 \\
1 / 45 \\
3 / 44 \\
1 / 45 \\
7 / 42 \\
1 / 43 \\
2 / 35 \\
6 / 44 \\
10 / 32 \\
7 / 35 \\
5 / 42 \\
11 / 40 \\
6 / 38 \\
9 / 38 \\
-148 \\
1 / 42 \\
1 / 41 \\
9 / 42 \\
6 / 36 \\
1 / 36 \\
10 / 45\end{array}$ \\
\hline
\end{tabular}

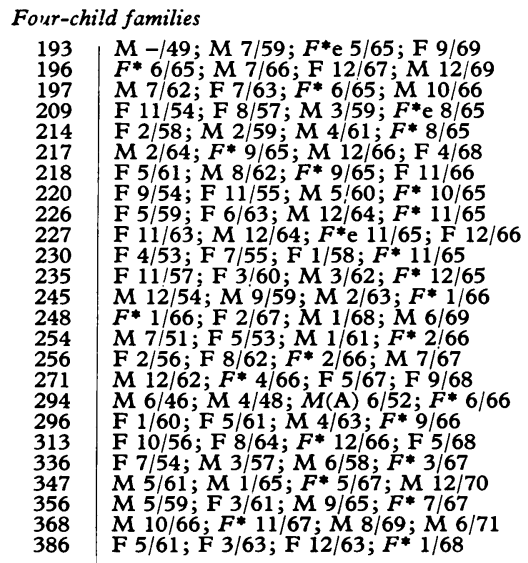

Five-child families

$192 \mid F^{*} 5 / 65 ;$ F 8/66; M 7/67; F 7/68; F 6/70

233 F 9/59; M 12/60; F 10/62; M 2/64; $F^{*} 12 / 65$

$239 M$ 6/59; M 7/60;F 7/62;M 6/63; F* $12 / 65$

243 [M 12/55;M 12/55]; $M$ 2/57; $F^{*} 1 / 66$;

286 F 10/59; M 4/61; M 6/62; F 9/63; F*6/66

$286 \quad \mathrm{M} 10 / 59 ; M 4 / 61 ; M 6 / 62 ; \mathrm{F} 9 / 63 ; F * 6 / 66$

$295 \quad M 10 / 63 ; M \quad 9 / 64 ; F / 8 / 66 ; F 1 / 67 ; M 12 / 68$

$312 \quad F 4 / 58 ; M 8 / 59 ; F$ F/62; M 11/64; $F^{*} 12 / 66$

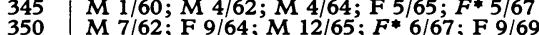

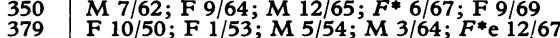

394 F $-150 ; M-/ 52 ; \mathrm{F}-154 ; \mathrm{F} 12 / 64 ; F^{*} 3 / 68$ 
Appendix I Continued

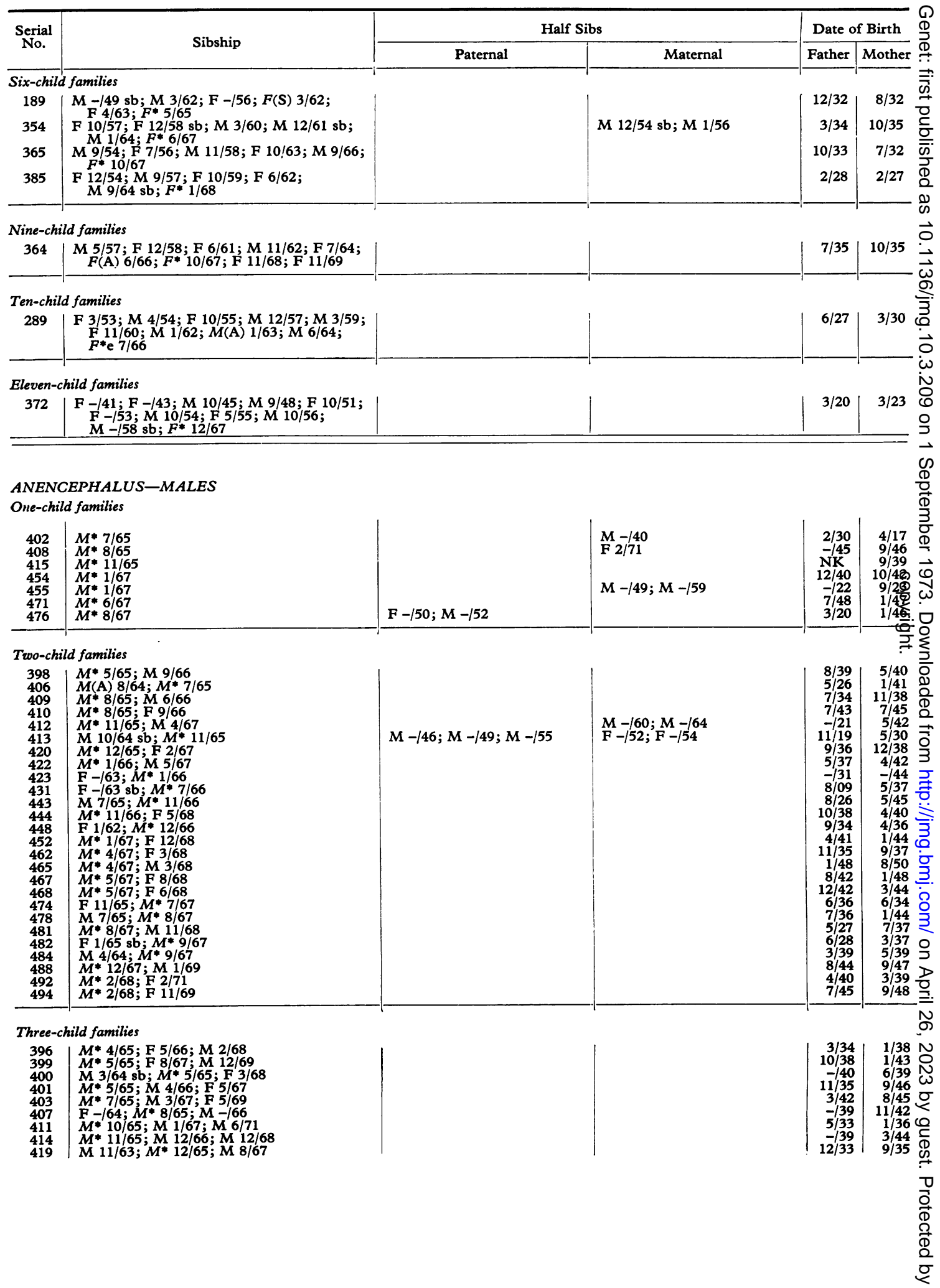


Appendix I Continued

\begin{tabular}{|c|c|c|c|c|c|}
\hline \multirow{2}{*}{$\begin{array}{l}\text { Serial } \\
\text { No. }\end{array}$} & \multirow{2}{*}{ Sibship } & \multicolumn{2}{|c|}{ Half Sibs } & \multicolumn{2}{|c|}{ Date of Birth } \\
\hline & & Paternal & Maternal & Father & Mother \\
\hline $\begin{array}{l}424 \\
427 \\
428 \\
429 \\
432 \\
433 \\
434 \\
435 \\
436 \\
437 \\
438 \\
442 \\
447 \\
449 \\
450 \\
457 \\
458 \\
459 \\
460 \\
461 \\
463 \\
466 \\
469 \\
470 \\
472 \\
473 \\
477 \\
479 \\
480 \\
483 \\
487 \\
489 \\
490 \\
496\end{array}$ & 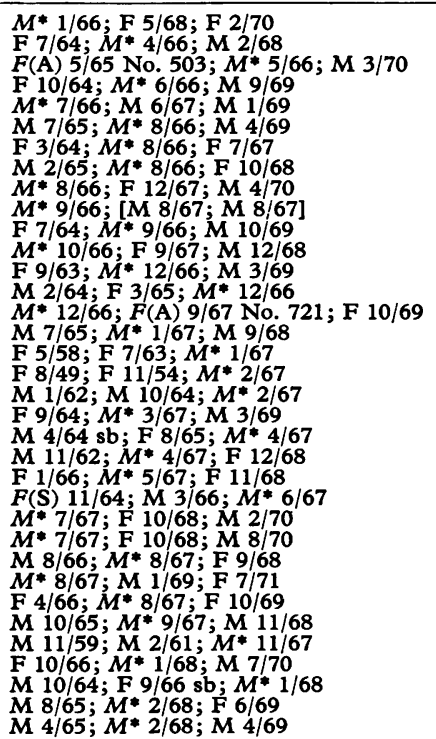 & & $F(\mathbf{S}) 7 / 53$ & $\begin{array}{r}7 / 39 \\
6 / 38 \\
3 / 26 \\
2 / 41 \\
-/ 39 \\
7 / 42 \\
8 / 41 \\
3 / 39 \\
8 / 42 \\
8 / 46 \\
10 / 40 \\
8 / 39 \\
9 / 36 \\
3 / 39 \\
7 / 47 \\
4 / 40 \\
4 / 31 \\
5 / 24 \\
2 / 41 \\
N K \\
10 / 32 \\
11 / 35 \\
10 / 39 \\
6 / 45 \\
10 / 31 \\
-/ 44 \\
7 / 43 \\
9 / 46 \\
4 / 45 \\
6 / 41 \\
11 / 32 \\
1 / 43 \\
1 / 32 \\
10 / 39 \\
5 / 28\end{array}$ & $\begin{array}{r}2 / 44 \\
1 / 41 \\
3 / 35 \\
2 / 44 \\
7 / 42 \\
8 / 46 \\
10 / 40 \\
5 / 40 \\
4 / 45 \\
4 / 45 \\
7 / 42 \\
10 / 42 \\
4 / 38 \\
3 / 42 \\
3 / 49 \\
6 / 39 \\
7 / 33 \\
5 / 26 \\
10 / 42 \\
9 / 39 \\
3 / 36 \\
7 / 38 \\
5 / 45 \\
11 / 45 \\
7 / 41 \\
8 / 42 \\
4 / 43 \\
10 / 44 \\
9 / 48 \\
12 / 42 \\
2 / 36 \\
10 / 39 \\
9 / 33 \\
12 / 40 \\
4 / 31\end{array}$ \\
\hline
\end{tabular}

Four-child families

$397 \mid$ F 8/61; M 12/63; $M^{*} 4 / 65 ;$ F 10/67

$416 \quad M-/ 61 \mathrm{sb} ; M \quad 2 / 64 ; M^{*} 11 / 65 ; M 9 / 67$

$417 \quad M^{*} 12 / 65 ; \mathrm{F} 2 / 67 ;[\mathrm{F} 11 / 68 ; \mathrm{F}$ 11/68]

418 F(S) 5/58; $M^{*} 12 / 65 ;$ F $12 / 66 ; \mathrm{F} 11 / 69$

$426 \quad M 2 / 62 ; M 1 / 64 ; M^{*} 3 / 66 ; M 2 / 68$

$430 M^{*} 6 / 66 ; M$ $5 / 67 ; \mathrm{F} 10 / 68 ; M 9 / 70$

$439 M^{*} 9 / 66 ; M$ 8/67; M 2/70 sb; F $1 / 71$

$440 \quad M^{*} 10 / 66$; F $10 / 67$; M 10/69; F 8/7

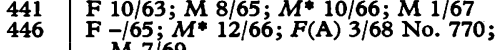

M 7/69

F $12 / 55 ;$ F $3 / 58$; F $2 / 60 ; M^{*} 12 / 66$

$M 8 / 63 ; M^{*} 1 / 67 ; M 1 / 69$ sb; $M 11 / 70$

$M ~ 5 / 55 ; M ~ 3 / 57 ; M ~ 9 / 58 ; M^{*} 10 / 67$

$\mathrm{F} 1 / 56 ; \mathrm{F} 6 / 57 ; M 1 / 60 ; M^{*} 2 / 68$

$M 12 / 66 ; M^{*} 3 / 68 ; F 5 / 69 ; M 8 / 70$

\begin{tabular}{r|r}
$5 / 28$ & $4 / 31$ \\
$9 / 37$ & $8 / 41$ \\
$11 / 36$ & $10 / 43$ \\
$9 / 33$ & $5 / 35$ \\
$8 / 26$ & $3 / 27$ \\
$2 / 38$ & $3 / 39$ \\
$8 / 44$ & $4 / 45$ \\
$5 / 39$ & $1 / 43$ \\
$5 / 42$ & $2 / 47$ \\
$1 / 42$ & $9 / 41$ \\
-142 & $4 / 43$ \\
$-/ 25$ & $7 / 30$ \\
-136 & $8 / 38$ \\
$3 / 30$ & $8 / 30$ \\
$5 / 31$ & $6 / 35$ \\
$9 / 39$ & $4 / 46$ \\
\hline
\end{tabular}

Five-child families

401 F 8/55; F 12/57; M 9/59; M 8/61; $M^{*} 7 / 65$

$405 \quad M 5 / 59 ; M 8 / 60 ; M 3 / 64 ; M^{*} 7 / 65 ; M 9 / 66$

453 F 12/58; $112 / 59 ; \mathrm{F}_{1 / 1} ; M^{*} 1167 ; \mathrm{F}_{1 / 68}$

$475 \quad M-158 ; F-159 ; M 2 / 60 ; M^{*} 8 / 67 ; M 9 / 69$

$491 \quad M 1 / 54 ; M 12 / 60 ; M 1 / 65 ; F$ 6/66; $\left[M^{*} 1 / 68 ; F(A) 1 / 68\right.$ No. 755$]$

\footnotetext{
Six-child families

$395 \mid$ M 7/55; F 4/57; M 8/59; F 12/61; M 12/63;

$425 \quad M \quad \begin{aligned} & M * 4 / 65 \\ & 1 / 57 ; M\end{aligned} 8 / 58 ; M ~ 11 / 59 ; M ~ 2 / 64 ; F 2 / 65$;

$445 \quad F \quad 9 / 61 ; M ~ 5 / 63 ; M ~ 1 / 65 ; M^{*} 11 / 66$;

$464 \quad \begin{aligned} & M 12 / 68 ; F \\ & \text { F }-161 ; M \\ & M^{*} 4 / 67\end{aligned}$
}

Thirteen-shild families

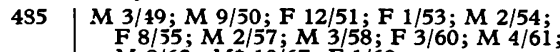
$M 8 / 62 ; M^{*} 10 / 67 ; F_{1 / 69}$ 
Appendix I Continued

\begin{tabular}{|c|c|c|c|c|c|}
\hline \multirow{2}{*}{$\begin{array}{l}\text { Serial } \\
\text { No. }\end{array}$} & \multirow{2}{*}{ Sibship } & \multicolumn{2}{|c|}{ Half Sibs } & \multicolumn{2}{|c|}{ Date of Birth } \\
\hline & & Paternal & Maternal & Father & Mother \\
\hline \multicolumn{6}{|c|}{ ANENCEPHALUS-FEMALES } \\
\hline \multicolumn{6}{|c|}{ One-child families } \\
\hline $\begin{array}{l}499 \\
501 \\
504 \\
512 \\
528 \\
532 \\
536 \\
539 \\
546 \\
563 \\
565 \\
576\end{array}$ & \begin{tabular}{|l}
{$\left[F^{*} 4 / 65 ; \mathrm{F} 4 / 65\right]$} \\
$F^{*} 5 / 65$ \\
$F^{*} 5 / 65$ \\
$F^{*} 6 / 65$ \\
$F^{*} 8 / 65$ \\
$F^{*} 8 / 65$ \\
$F^{*} 965$ \\
$F^{*} 10 / 65$ \\
$F^{*} 11 / 65$ \\
$F^{*} 1 / 66$ \\
$F^{*} 1 / 66$ \\
{$\left[\mathrm{~F} 3 / 66 ; F^{*} 3 / 66\right]$}
\end{tabular} & $\begin{array}{l}M-/ 46 \\
M-150 ; F-/ 56 \\
F-/ 47 ; F-149 ; F-152 ;\end{array}$ & $\begin{array}{l}\text { F } 3 / 60 ; M 4 / 63 ; M 3 / 67 \\
\text { F } 9 / 54 ; F 6 / 64\end{array}$ & $\begin{array}{c}\mathrm{NK} \\
7 / 32 \\
5 / 30 \\
5 / 20 \\
9 / 23 \\
9 / 40 \\
\mathrm{NK} \\
5 / 43 \\
12 / 36 \\
6 / 14 \\
-144 \\
12 / 36\end{array}$ & $\begin{array}{l}11 / 43 \\
3 / 34 \\
6 / 33 \\
5 / 26 \\
6 / 33 \\
1 / 41 \\
5 / 41 \\
2 / 45 \\
5 / 43 \\
7 / 25 \\
9 / 39 \\
7 / 34\end{array}$ \\
\hline $\begin{array}{l}577 \\
591 \\
593 \\
599 \\
605 \\
612 \\
647 \\
648 \\
655 \\
659 \\
653 \\
669 \\
671 \\
685 \\
686 \\
687 \\
688 \\
690 \\
700 \\
703 \\
710 \\
714 \\
720 \\
723 \\
738 \\
743 \\
764 \\
766\end{array}$ & 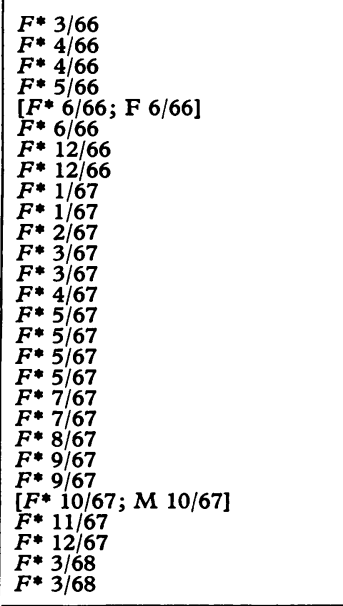 & $\begin{array}{l}M-/ 60 ; M-162 \\
F-156 ; F-/ 57 ; M-/ 59\end{array}$ & 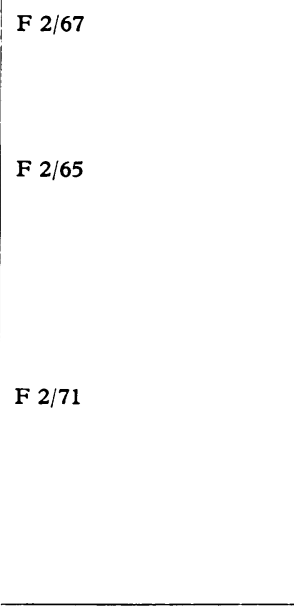 & $\begin{array}{c}\mathrm{NK} \\
12 / 48 \\
101 / 21 \\
9 / 39 \\
7 / 45 \\
2 / 44 \\
8 / 38 \\
2 / 36 \\
3 / 46 \\
11 / 32 \\
5 / 38 \\
-147 \\
7 / 43 \\
6 / 46 \\
\mathrm{NK} \\
12 / 46 \\
9 / 30 \\
10 / 21 \\
-/ 45 \\
3 / 40 \\
1 / 43 \\
4 / 30 \\
3 / 32 \\
7 / 20 \\
7 / 49 \\
4 / 43 \\
10 / 37 \\
-/ 32\end{array}$ & $\begin{array}{l}12 / 46 \\
12 / 48 \\
8 / 41 \\
8 / 43 \\
8 / 46 \\
9 / 44 \\
10 / 44 \\
6 / 44 \\
8 / 47 \\
3 / 34 \\
1 / 36 \\
1 / 1 / 49 \\
5 / 45 \\
5 / 47 \\
4 / 50 \\
7 / 47 \\
11 / 27 \\
12 / 44 \\
10 / 46 \\
3 / 44 \\
5 / 44 \\
7 / 32 \\
2 / 338 \\
6 / 378 \\
1 / 49 \\
7 / 42 \\
1 / 420 \\
1 / 34\end{array}$ \\
\hline \multicolumn{6}{|c|}{ Two-child families } \\
\hline $\begin{array}{l}498 \\
506 \\
513 \\
526 \\
541 \\
544 \\
548 \\
552 \\
559 \\
561 \\
562 \\
569 \\
573 \\
574 \\
584 \\
587 \\
594 \\
596 \\
600 \\
601 \\
610 \\
613 \\
615 \\
616 \\
618 \\
624 \\
628 \\
630 \\
631 \\
634 \\
635 \\
637 \\
638 \\
642 \\
649\end{array}$ & 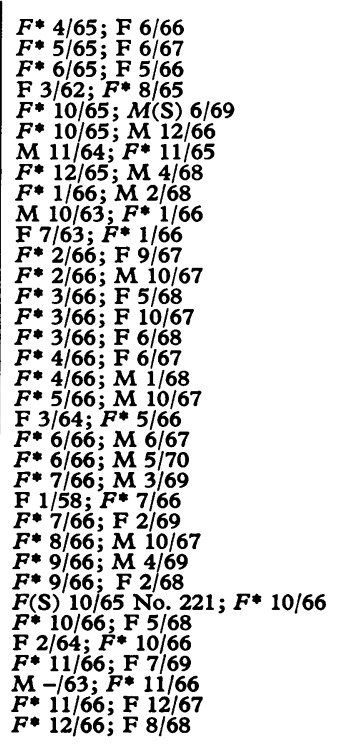 & $\mathrm{F}-158$ & $M 2 / 57 ; F 6 / 58 ; M 11 / 60$ & $\begin{array}{r}2 / 40 \\
6 / 37 \\
2 / 16 \\
4 / 26 \\
3 / 37 \\
N K \\
2 / 35 \\
5 / 42 \\
11 / 35 \\
\text { NK } \\
3 / 32 \\
3 / 28 \\
11 / 38 \\
1 / 33 \\
1 / 44 \\
11 / 43 \\
12 / 35 \\
12 / 43 \\
8 / 40 \\
4 / 37 \\
3 / 36 \\
11 / 39 \\
5 / 31 \\
5 / 35 \\
9 / 43 \\
10 / 38 \\
12 / 43 \\
11 / 37 \\
4 / 35 \\
10 / 48 \\
9 / 27 \\
1 / 40 \\
3 / 43 \\
9 / 30 \\
-1 / 35\end{array}$ & $\begin{array}{r}2 / 43 \\
1 / 38 \\
2 / 46 \\
5 / 31 \\
2 / 43 \\
6 / 27 \\
3 / 40 \\
12 / 46 \\
12 / 41 \\
3 / 35 \\
11 / 38 \\
3 / 36 \\
12 / 39 \\
3 / 33 \\
3 / 45 \\
6 / 45 \\
12 / 34 \\
3 / 42 \\
10 / 35 \\
1 / 44 \\
3 / 45 \\
4 / 42 \\
7 / 29 \\
8 / 37 \\
3 / 47 \\
7 / 38 \\
5 / 46 \\
1 / 47 \\
2 / 40 \\
11 / 47 \\
12 / 32 \\
3 / 29 \\
12 / 42 \\
9 / 37 \\
1 / 37\end{array}$ \\
\hline
\end{tabular}


Appendix I Continued

\begin{tabular}{|c|c|c|c|c|c|}
\hline \multirow{2}{*}{$\begin{array}{c}\text { Serial } \\
\text { No. }\end{array}$} & \multirow{2}{*}{ Sibship } & \multicolumn{2}{|c|}{ Half Sibs } & \multicolumn{2}{|c|}{ Date of Birth } \\
\hline & & Paternal & Maternal & Father & Mother \\
\hline $\begin{array}{l}650 \\
651 \\
654 \\
668 \\
670 \\
672 \\
676 \\
689 \\
691 \\
692 \\
693 \\
696 \\
699 \\
709 \\
723 \\
728 \\
730 \\
732 \\
734 \\
736 \\
737 \\
740 \\
744 \\
749 \\
750 \\
752 \\
758 \\
760 \\
767\end{array}$ & 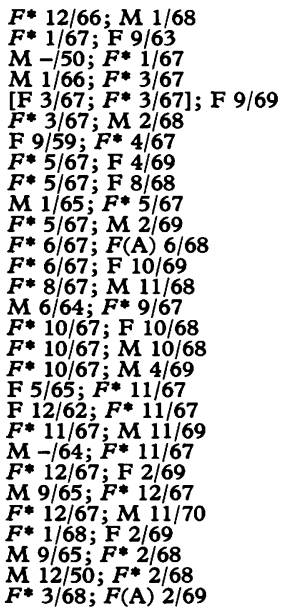 & $M-/ 56 ; F-/ 57$ & F $7 / 71$ & $\begin{array}{r}6 / 37 \\
12 / 37 \\
5 / 13 \\
7 / 42 \\
9 / 41 \\
10 / 43 \\
11 / 35 \\
10 / 43 \\
4 / 47 \\
2 / 40 \\
-123 \\
12 / 36 \\
5 / 45 \\
9 / 41 \\
-127 \\
7 / 44 \\
9 / 45 \\
12 / 36 \\
6 / 44 \\
7 / 37 \\
4 / 45 \\
3 / 31 \\
9 / 44 \\
9 / 41 \\
9 / 47 \\
12 / 46 \\
-128 \\
8 / 18 \\
6 / 45\end{array}$ & $\begin{array}{r}5 / 42 \\
9 / 34 \\
11 / 20 \\
5 / 44 \\
10 / 42 \\
2 / 49 \\
10 / 36 \\
4 / 46 \\
2 / 48 \\
6 / 45 \\
3 / 49 \\
8 / 38 \\
12 / 46 \\
9 / 44 \\
11 / 38 \\
6 / 44 \\
10 / 48 \\
2 / 31 \\
7 / 46 \\
3 / 41 \\
8 / 44 \\
1 / 43 \\
6 / 47 \\
8 / 47 \\
2 / 48 \\
7 / 49 \\
7 / 36 \\
9 / 24 \\
8 / 49\end{array}$ \\
\hline
\end{tabular}

Three-child families

$502 \mid \mathrm{M} 7 / 63 ; F^{*} 5 / 65 ; \mathrm{F} 4 / 66$

$503 \quad 5 / 65 ; M(A) 5 / 66$ No. $428 ; M 3 / 70$

$505 \quad M \quad 5 / 60 ; \mathrm{F} 7 / 61 ; F^{*} 5 / 65$

$508 \quad F^{*} 5 / 65 ;$ F $12 / 67 ; M(A) 11 / 69$

$510 \quad M \quad 3 / 63 ; F * 6 / 65 ; M 4 / 67$

$515 \quad F^{*} 7 / 65 ; \mathrm{F} 4 / 67 ; \mathrm{F} 1 / 70$

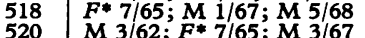

$524 \quad F 9 / 64 ; F * 8 / 65 ; M 7 / 66$

$529 \quad M$ 9/63; $F^{*} 8 / 65 ; F(A) 3 / 67$ No. 667

$530 \quad F^{*} 8 / 65 ; M 11 / 66 ; M 9 / 70$

$531 \quad F * 8 / 65 ; \mathrm{F} 3 / 67 ; \mathrm{F} 12 / 68$

$533 \quad$ F $2 / 59 ; M 2 / 63 ; F * 8 / 65$

537 [F $1 / 61 ; M 1 / 61] ; F^{*} 9 / 65$

$540 \quad F^{*} 10 / 65 ; M$ 9/66; M 12/69

$542 \quad M 9 / 61 ; F^{*} 10 / 65 ; F 7 / 67$

$543 F^{*} 10 / 65 ; \mathrm{F} 11 / 66 ; \mathrm{M} \mathrm{9/68}$

$545 \quad F * 10 / 65 ; M ~ 2 / 67 ; M ~ 1 / 68$

549 F $1 / 55 ;$ F 12/56; F* $11 / 65$

$550 \quad F^{*} 12 / 65 ; \mathrm{F} 10 / 66 ;$ F $5 / 68$

$553 \quad F^{*} 12 / 65 ; \mathrm{F}$ 6/67; F 7/69

554 F $11 / 58 ; F * 12 / 65 ;$ F $1 / 67$

$556 \quad F * 12 / 65 ; \mathrm{F} \mathrm{12/68}$; F 12/69

$557 \quad F^{*} 12 / 65 ; \mathrm{F} 6 / 67 ; M 3 / 70$

$564 \mathrm{M} \mathrm{5/61;M} \mathrm{12/63;F^{* } 1 / 6 6}$

$566 \quad F^{*} 2 / 66 ; \mathrm{F} 9 / 67 ; M 1 / 69$

$567 \quad M 7 / 51 ; M 2 / 53 ; F^{*} 2 / 66$

$568 \quad F 11 / 61 ; F^{*} 2 / 66 ; M 8 / 67$

$572 \quad M \quad 11 / 51 ; M 7 / 56 ; F^{*} 2 / 66$

575 F $7 / 64 ; F * 3 / 66 ; M 1 / 70$

579 M 4/61; F 3/63; $F * 3 / 66$

580

$F * 3 / 66 ; M ~ 2 / 67 ; M ~ 1 / 69$

$F * 3 / 66 ; \mathrm{F} 5 / 67 ; M$ 5/68

$F * 3 / 66 ; M$ 6/67; F 5/69

F $2 / 62 ; F * 4 / 66 ; M 7 / 67$

$F^{*} 4 / 66 ; M$ 3/67; M 6/69

F $1 / 60 ; M ~ 9 / 63 ; F^{*} 4 / 66$

F $4 / 60 ; M 3 / 63 ; F * 6 / 66$

$F^{*} 6 / 66 ; M$ 7/67; $M 1 / 70$

$F *$ 6/66; F 5/67; M 8/69

F $10 / 61 ; \mathrm{F} 5 / 64 ; F * 6 / 66$

F* $10 / 61 ;$ F $5 / 64 ; F * 6 / 66$

$F^{*}$ 6/66; F6/67; $M 2 / 70$

$F * 6 / 66 ; M 7 / 67 ; M 6 / 69$

F 8/65; $F^{*} 6 / 66 ; M 11 / 68$

$F^{*} 6 / 66 ; F$ F/68; M 5/69
F $1 / 65 ; F * 6 / 66 ; M$
$M / 68$

F $1 / 65 ; F * 6 / 66 ; M$ 5/68

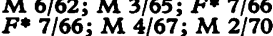

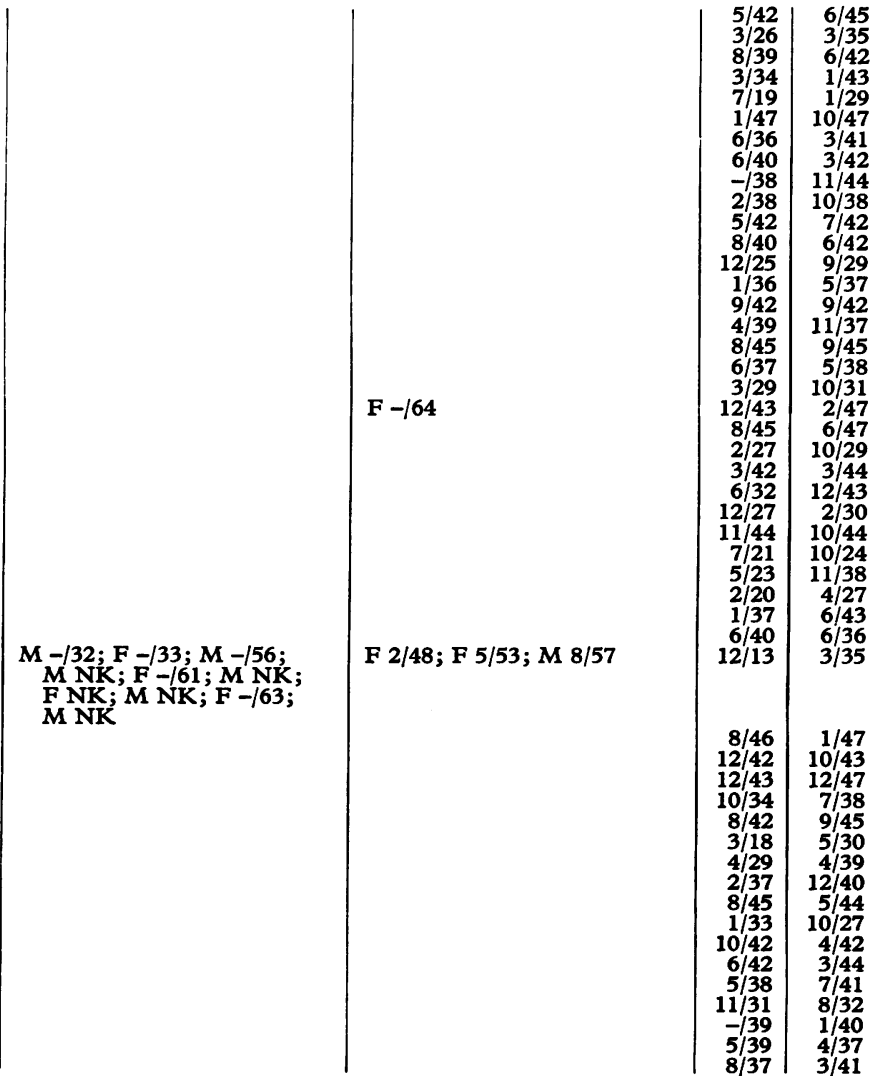


Appendix I Continued

\begin{tabular}{|c|c|c|c|c|c|}
\hline \multirow{2}{*}{$\begin{array}{l}\text { Serial } \\
\text { No. }\end{array}$} & \multirow{2}{*}{ Sibship } & \multicolumn{2}{|c|}{ Half Sibs } & \multicolumn{2}{|c|}{ Гate of Pirth } \\
\hline & & Paternal & Maternal & Father & Mother \\
\hline $\begin{array}{l}623 \\
625 \\
629 \\
632 \\
633 \\
639 \\
640 \\
641 \\
644 \\
645 \\
646 \\
652 \\
653 \\
656 \\
658 \\
666 \\
667 \\
674 \\
675 \\
677 \\
678 \\
679 \\
630 \\
632 \\
683 \\
684 \\
694 \\
695 \\
697 \\
701 \\
707 \\
711 \\
712 \\
713 \\
716 \\
718 \\
721 \\
722 \\
724 \\
726 \\
729 \\
730 \\
739 \\
742 \\
746 \\
747 \\
748 \\
753 \\
754 \\
756 \\
757 \\
759 \\
762 \\
765 \\
768 \\
769 \\
771\end{array}$ & 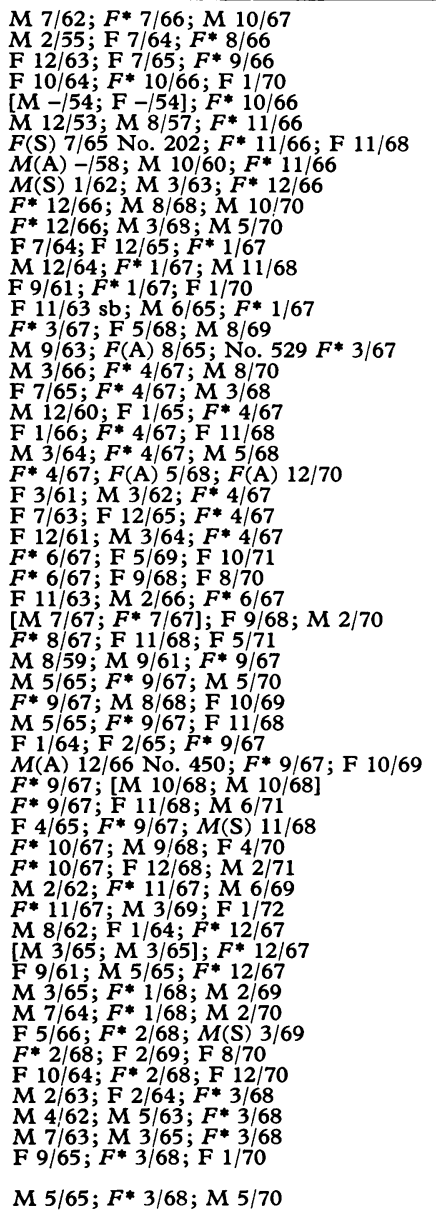 & $\begin{array}{c}M_{F}-/ 45 ; F-149 ; M-153 ; \\
\text { NK-/57 }\end{array}$ & F $12 / 62$ & $\begin{array}{r}7 / 35 \\
3 / 38 \\
6 / 34 \\
4 / 45 \\
-/ 28 \\
9 / 21 \\
3 / 40 \\
1 / 13 \\
12 / 36 \\
4 / 36 \\
11 / 42 \\
11 / 40 \\
2 / 40 \\
1 / 36 \\
11 / 36 \\
7 / 40 \\
2 / 38 \\
3 / 43 \\
10 / 39 \\
9 / 36 \\
12 / 36 \\
8 / 39 \\
10 / 40 \\
7 / 33 \\
3 / 40 \\
4 / 40 \\
1 / 47 \\
8 / 47 \\
5 / 30 \\
5 / 41 \\
4 / 40 \\
6 / 34 \\
7 / 40 \\
12 / 43 \\
11 / 29 \\
7 / 37 \\
7 / 47 \\
1 / 35 \\
3 / 47 \\
1 / 38 \\
7 / 41 \\
7 / 47 \\
2 / 36 \\
4 / 37 \\
9 / 36 \\
3 / 37 \\
3 / 33 \\
6 / 44 \\
1 / 39 \\
4 / 36 \\
6 / 33 \\
2 / 42 \\
9 / 40 \\
6 / 33 \\
6 / 39 \\
10 / 23 \\
12 / 41\end{array}$ & 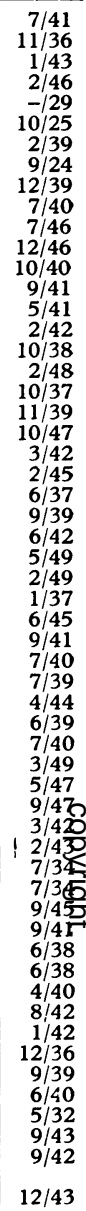 \\
\hline \multicolumn{6}{|c|}{ Four-child families } \\
\hline $\begin{array}{l}507 \\
509 \\
517 \\
519 \\
523 \\
525 \\
527 \\
560 \\
578 \\
581 \\
588 \\
598 \\
611 \\
617 \\
620 \\
627 \\
636 \\
643 \\
657 \\
660 \\
662 \\
665\end{array}$ & 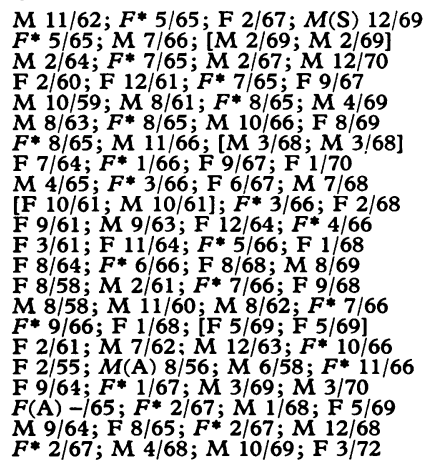 & F NK; $M-/ 56$ & & $\begin{aligned} 6 / 37 \\
11 / 32 \\
6 / 45 \\
1-135 \\
10 / 39 \\
4 / 35 \\
-136 \\
8 / 36 \\
3 / 46 \\
2 / 37 \\
4 / 39 \\
1 / 30 \\
3 / 44 \\
4 / 36 \\
11 / 31 \\
2 / 34 \\
8 / 34 \\
4 / 28 \\
12 / 43 \\
6 / 30 \\
3 / 33 \\
11 / 45\end{aligned}$ & \begin{tabular}{|r|}
$8 / 42$ \\
$9 / 45$ \\
$1 / 45$ \\
$5 / 38$ \\
$6 / 36$ \\
$6 / 40$ \\
$4 / 39$ \\
$1 / 41$ \\
$12 / 44$ \\
$3 / 41$ \\
$12 / 39$ \\
$1 / 32$ \\
$1 / 45$ \\
1035 \\
$12 / 35$ \\
$1 / 43$ \\
533 \\
$4 / 33$ \\
$2 / 46$ \\
$4 / 33$ \\
$6 / 36$ \\
$1 / 45$
\end{tabular} \\
\hline
\end{tabular}


Appendix I Continued

\begin{tabular}{|c|c|c|c|c|c|}
\hline \multirow{2}{*}{$\begin{array}{l}\text { Serial } \\
\text { No. }\end{array}$} & \multirow{2}{*}{ Sibship } & \multicolumn{2}{|c|}{ Half Sibs } & \multicolumn{2}{|c|}{ Date of Birth } \\
\hline & & Paternal & Maternal & Father & Mother \\
\hline $\begin{array}{l}702 \\
705 \\
715 \\
719 \\
725 \\
741 \\
745 \\
751 \\
761 \\
763 \\
770\end{array}$ & $\begin{array}{l}\text { M } 1 / 66 ;\left[F^{*} 7 / 67 ; M 7 / 67\right] ; M 6 / 68 ; M 12 / 69 \\
\text { F } 2 / 65 ; F^{*} 7 / 67 ; F 11 / 69 ; F 6 / 71 \\
\text { F } 7 / 61 ; F 1 / 63 ; F^{*} 9 / 67 ; F 10 / 68 \\
M \quad 11 / 65 ; F^{*} 9 / 67 ; F 8 / 68 ; M 1 / 70 \\
M \quad 4 / 61 ; M 4 / 63 ; F(A) 7 / 64 ; F^{*} 9 / 67 \\
M 12 / 61 ; F 10 / 66 ; F^{*} 11 / 67 ; M 4 / 70 \\
\text { M } 2 / 62 ; F 11 / 61 ; M 7 / 66 ; F^{*} 12 / 67 \\
\text { M } 8 / 61 ; M 7 / 66 ; F^{*} 12 / 67 ; M 5 / 69 \\
\text { F } 9 / 62 ; F 6 / 61 ; F^{*} 3 / 68 ; M 3 / 69 \\
\text { M } 10 / 59 ; F 1 / 61 ; F 1 / 64 ; F^{*} 3 / 68 \\
\text { F } 6 / 65 ; M(A) 12 / 65 \text { No. } 446 ; F^{*} 3 / 68 ; \\
\text { M } 7 / 69\end{array}$ & & $\begin{array}{l}\text { F }-159 \\
\text { F } 2 / 56 ; \text { F } 4 / 60 ; M ~ \\
\text { M } 2 / 55 ; \text { F } 9 / 56\end{array}$ & $\begin{array}{r}6 / 45 \\
8 / 38 \\
3 / 36 \\
-130 \\
6 / 32 \\
11 / 37 \\
8 / 33 \\
2 / 39 \\
3 / 41 \\
4 / 32 \\
-142\end{array}$ & $\begin{array}{r}6 / 47 \\
1 / 42 \\
11 / 41 \\
3 / 31 \\
1 / 39 \\
3 / 41 \\
6 / 43 \\
12 / 39 \\
12 / 41 \\
10 / 27 \\
4 / 43\end{array}$ \\
\hline \multicolumn{6}{|c|}{ Five-child families } \\
\hline 511 & $\begin{array}{l}\mathrm{M}_{F^{*} / 6 / 65}-/ 45-/ 47 ; M-/ 51 ; F(\mathrm{~A}) 4 / 56 \\
\text {; }\end{array}$ & & & $1 / 17$ & $3 / 22$ \\
\hline $\begin{array}{l}514 \\
516 \\
534\end{array}$ & $\begin{array}{l}\text { M } 11 / 59 ; M 6 / 61 ; \mathrm{F} 1 / 63 ; F^{*} 7 / 65 ; \mathrm{F} 10 / 66 \\
\mathrm{M} 8 / 55 ; \mathrm{F} 3 / 59 ; \mathrm{F} 10 / 63 ; F^{*} 7 / 65 ; \mathrm{M} 3 / 67 \\
\text { F } 6 / 60 ; M(\mathrm{~S}) 7 / 61 ; \mathrm{F} 7 / 63 ; F^{*} 9 / 65 ; \\
\quad \text { F } 9 / 67\end{array}$ & & & $\begin{array}{r}-/ 37 \\
10 / 32 \\
11 / 36\end{array}$ & $\begin{array}{r}6 / 39 \\
12 / 31 \\
7 / 39\end{array}$ \\
\hline 535 & $\underset{F}{F(\mathrm{~A})} \stackrel{9 / 60}{9 / 65} ;[\mathrm{M} 9 / 61 \mathrm{sb} ; \mathrm{M} 9 / 61 \mathrm{sb}] ; \mathrm{F} 11 / 64 ;$ & & & $12 / 31$ & $3 / 37$ \\
\hline 538 & $\mathrm{M}_{F^{*}}^{4 / 53 ; \mathrm{F}} 11 / 65$ & & & $8 / 25$ & $8 / 29$ \\
\hline $\begin{array}{l}547 \\
551\end{array}$ & $\begin{array}{l}M 3 / 55 ; M 6 / 57 ; M 4 / 59 ; M ~ 5 / 61 ; F^{*} 11 / 65 \\
M 6 / 62 ; F^{*} 12 / 65 ; M 4 / 67 ; F 3 / 68 \mathrm{sb} ; \\
\text { M } 1 / 70\end{array}$ & & & $\begin{array}{l}6 / 28 \\
1 / 37\end{array}$ & $\begin{array}{l}4 / 36 \\
6 / 36\end{array}$ \\
\hline $\begin{array}{l}571 \\
582 \\
583\end{array}$ & $\begin{array}{l}\text { M } 5 / 58 ; \mathrm{F} 3 / 60 ; \mathrm{F} 2 / 62 ; F^{*} 2 / 66 ; \mathrm{M} 10 / 67 \\
\text { M } 10 / 61 ; \mathrm{F} 3 / 63 ; F^{*} 3 / 66 ; \mathrm{F} 2 / 67 ; \mathrm{F} 4 / 69 \\
\text { M } 6 / 61 ; M(\mathrm{~A}) 8 / 64 ; F^{*} 3 / 66 ; \mathrm{F} 5 / 67 ; \\
\text { F } 11 / 69\end{array}$ & & & $\begin{array}{l}3 / 34 \\
7 / 36 \\
5 / 39\end{array}$ & $\begin{array}{r}11 / 39 \\
8 / 41 \\
10 / 37\end{array}$ \\
\hline $\begin{array}{l}590 \\
619\end{array}$ & $\begin{array}{l}\text { F } 3 / 63 ; F^{*} 4 / 66 ; \mathrm{F} 8 / 68 ; \mathrm{F} 1 / 70 ; \mathrm{F} 3 / 71 \\
\mathrm{M} 2 / 61 ; \mathrm{M} 3 / 63 ; M(\mathrm{~S}) 4 / 65 ; F^{*} 7 / 66 \\
\quad \mathrm{M} 5 / 68\end{array}$ & & & $\begin{array}{l}1 / 43 \\
1 / 38\end{array}$ & $\begin{array}{l}7 / 43 \\
7 / 42\end{array}$ \\
\hline $\begin{array}{l}626 \\
661 \\
664 \\
673 \\
681\end{array}$ & 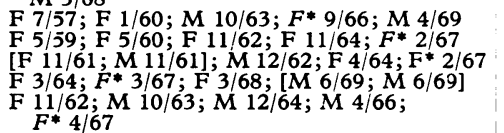 & & & $\begin{array}{r}12 / 30 \\
11 / 27 \\
-/ 32 \\
5 / 38 \\
7 / 39\end{array}$ & $\begin{array}{l}1 / 37 \\
8 / 35 \\
1 / 29 \\
9 / 40 \\
9 / 42\end{array}$ \\
\hline 698 & $\begin{array}{l}{[\mathrm{F} 8 / 64 \mathrm{sb} ; \mathrm{F} 8 / 64] ; M 3 / 66 ; F^{*} 6 / 67} \\
F(S) 12 / 68\end{array}$ & & 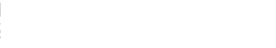 & $3 / 37$ & $7 / 37$ \\
\hline $\begin{array}{l}706 \\
708 \\
717 \\
735\end{array}$ & $\begin{array}{l}M 7 / 64 ; M 8 / 66 ; F^{*} 8 / 67 ; M 4 / 69 ; M 11 / 71 \\
\mathrm{~F}-156 ; M-/ 62 ; \mathrm{F} 1 / 66 \mathrm{sb} ; F^{*} 8 / 67 ; M 11 / 69 \\
\mathrm{M} 6 / 59 ; \mathrm{F} / 61 ; \mathrm{F} 10 / 63 ; \mathrm{M} 2 / 65 ; F^{*} 9 / 67 \\
F(\mathrm{~S}) 10 / 60 ; M 1 / 62 ; F(\mathrm{~S}) 5 / 64 ; M^{*} 4 / 65 ; \\
F^{*} 11 / 67\end{array}$ & & & $\begin{array}{r}1 / 43 \\
9 / 36 \\
11 / 34 \\
11 / 33\end{array}$ & $\begin{array}{r}8 / 44 \\
2 / 38 \\
12 / 37 \\
8 / 35\end{array}$ \\
\hline 755 & $\begin{array}{l}M 1 / 54 ; M 12 / 60 ; M 1 / 65 ; F 6 / 66 ; \\
{\left[M(A) 1 / 68 \text { No. } 491 ; F^{*} 1 / 68\right]}\end{array}$ & & & $11 / 28$ & $7 / 32$ \\
\hline \multicolumn{6}{|c|}{ Six-child families } \\
\hline 500 & $\begin{array}{l}\text { M } 3 / 58 \mathrm{sb} ; \mathrm{M} 6 / 59 ; F(\mathrm{~A}) 2 / 61 ; \mathrm{F} 2 / 62 ; \\
{\left[\mathrm{F} 4 / 65 \mathrm{sb} ; F^{*} 4 / 65\right] ; M 9 / 66}\end{array}$ & & & $3 / 27$ & \\
\hline 522 & $\begin{array}{l}\text { F } 12 / 57 ; \text { F } 2 / 59 ; F(S) 4 / 61 ; F^{*} 7 / 65 ; \\
\text { F } 1 / 68 ; \text { F } 1 / 69\end{array}$ & & & $7 / 21$ & $11 / 37$ \\
\hline 555 & $\begin{array}{l}\text { M 7/56;M 11/58; M 5/67; F* 12/65; } \\
\text { F 2/69; F } 7 / 70\end{array}$ & & & $2 / 35$ & $9 / 36$ \\
\hline \multicolumn{6}{|c|}{ Seven-child families } \\
\hline 521 & $\begin{array}{l}\text { M } 7 / 51 ; F 4 / 54 ; M 3 / 55 ; M 3 / 56 ; M 4 / 59 ; \\
\quad M 1 / 61 ; F^{*} 7 / 65\end{array}$ & & & $12 / 25$ & $2 / 32$ \\
\hline 558 & $\begin{array}{l}\mathrm{F}-/ 51 ; \mathrm{M}-/ 52 ; \mathrm{F}-154 ; \mathrm{M}-/ 58 ; \mathrm{F}-/ 63 ; \\
F^{*} 12 / 65 ; \mathrm{M}-/ 67\end{array}$ & & & $1 / 23$ & $8 / 29$ \\
\hline 704 & $\begin{array}{l}\text { F } 1 / 50 ; \text { F } 11 / 51 ; M \\
\text { F } 9 / 63 ; F^{*} 7 / 67\end{array}$ & & & $10 / 30$ & $6 / 30$ \\
\hline 727 & $\begin{array}{l}\text { M } 3 / 52 ; M 2 / 53 ; F 3 / 57 ; \text { F } 4 / 59 ; M ~ 2 / 61 ; \\
\text { F } 6 / 62 ; F^{*} 9 / 67\end{array}$ & & & $9 / 26$ & $11 / 28$ \\
\hline
\end{tabular}




\section{Appendix II \\ Subsidiary Series}

M, male; F, female; *, index patient; italics indicate affected relative; [ ], twins; sb, stillbirth; $A$, anencephalus; $S$, spina bifida; e, encephalocele.

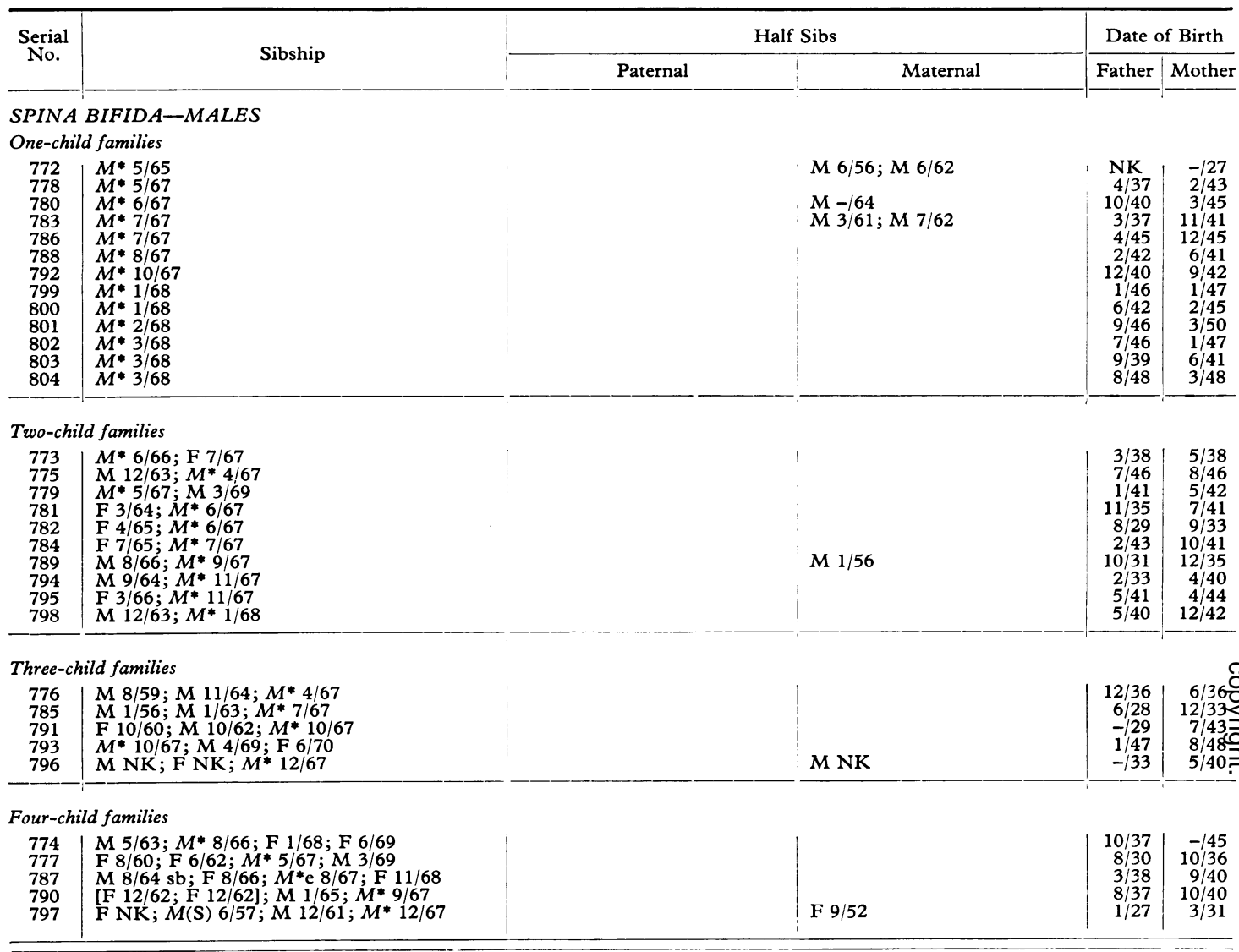

SPINA BIFIDA-FEMALES

\begin{tabular}{|c|c|}
\hline Dne-ch & families \\
\hline $\begin{array}{l}808 \\
812 \\
814 \\
818 \\
822 \\
828 \\
829 \\
833 \\
837 \\
838 \\
839 \\
840 \\
842 \\
844 \\
846 \\
849 \\
850 \\
852 \\
854\end{array}$ & $\begin{array}{l}F^{*} 2 / 66 \\
F^{*} 7 / 66 \\
F^{*} 3 / 67 \\
F^{*} 5 / 67 \\
F^{*} 6 / 67 \\
F^{*} 7 / 67 \\
F^{*} 7 / 67 \\
F^{*} 8 / 67 \\
F^{*} 9 / 67 \\
F^{*} 9 / 67 \\
F^{*} 9 / 67 \\
F^{*} 10 / 67 \\
F^{*} 11 / 67 \\
F^{*} 12 / 67 \\
F^{*} \mathrm{e} 1 / 68 \\
F^{*} 2 / 68 \\
F^{*} 2 / 68 \\
F^{*} 3 / 68 \\
F^{*} 3 / 68\end{array}$ \\
\hline
\end{tabular}

M 11/58; D $11 / 60 ;$ F 3/62 M 6/70

M $3 / 56 ; M 1 / 58 ; M 10 / 59$

F $10 / 64$

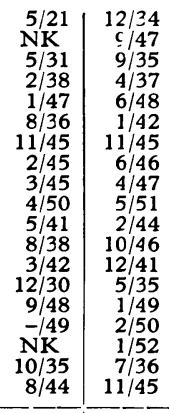

은

$\vec{\omega}$

48 군

Two-child families

$805 F^{*} 7 / 65 ; M \quad 1 / 69$

$809 \quad F^{*} 4 / 66 ; M 1 / 68$ 
Appendix II Continued

\begin{tabular}{|c|c|c|c|c|c|}
\hline \multirow{2}{*}{$\begin{array}{c}\text { Serial } \\
\text { No. }\end{array}$} & \multirow{2}{*}{ Sibship } & \multicolumn{2}{|c|}{ Half Sibs } & \multicolumn{2}{|c|}{ Date of Birth } \\
\hline & & Paternal & Maternal & Father & Mother \\
\hline $\begin{array}{l}810 \\
811 \\
815 \\
816 \\
819 \\
820 \\
823 \\
827 \\
830 \\
834 \\
835 \\
836 \\
841 \\
847 \\
853\end{array}$ & $\begin{array}{l}F^{*} 5 / 66 ; F(\mathrm{~A}) 2 / 68 \text { No. } 869 \\
M 1 / 65 ; F^{*} 7 / 66 \\
M 12 / 62 ; F^{*} 4 / 67 \\
F^{*} \mathrm{e} 4 / 67 ; M 8 / 68 \\
\mathrm{M} 2 / 66 ; F^{*} 5 / 67 \\
\mathrm{~F} 2 / 65 ; F^{*} \mathrm{e} 5 / 67 \\
F^{*} 6 / 67 ; \mathrm{F} 7 / 68 \\
F^{*} \mathrm{e} 7 / 67 ; M 4 / 69 \\
\mathrm{~F} 6 / 66 ; F^{*} 8 / 67 \\
M \quad 8 / 66 ; F^{*} 8 / 57 \\
M 2 / 64 ; F^{*} 8 / 67 \\
F^{*} 9 / 67 ; \mathrm{F} 12 / 68 \\
\mathrm{~F} 4 / 65 ; F^{*} 11 / 67 \\
F^{*} 1 / 68 ; M 12 / 70 \\
F^{*} 3 / 68 ; M 2 / 69\end{array}$ & & & $\begin{array}{r}9 / 38 \\
12 / 34 \\
2 / 40 \\
\text { NK } \\
10 / 30 \\
10 / 26 \\
7 / 47 \\
7 / 36 \\
1 / 40 \\
12 / 45 \\
3 / 42 \\
1 / 48 \\
1 / 41 \\
11 / 48 \\
6 / 44\end{array}$ & $\begin{array}{c}4 / 41 \\
10 / 44 \\
3 / 42 \\
N K \\
2 / 34 \\
7 / 37 \\
9 / 47 \\
3 / 39 \\
3 / 43 \\
4 / 48 \\
11 / 41 \\
12 / 48 \\
3 / 42 \\
3 / 49 \\
8 / 50\end{array}$ \\
\hline
\end{tabular}

Three-child families

\begin{tabular}{l|l}
806 & $F^{*} 10 / 65 ; M ~ 7 / 67 ; M 1 / 70$ \\
813 & M NK;M NK;F*9/66 \\
824 & M $12 / 58 ; M ~ 12 / 62 ; F^{*} 6 / 67$ \\
831 & F $9 / 65 ; F^{*} 8 / 67 ; M 5 / 69$ \\
832 & F $12 / 52 ;$ F $3 / 56 ; F^{*} 8 / 67$ \\
813 & F $6 / 54 ;$ F $9 / 55 ; F^{*}$ e $12 / 67$ \\
848 & F $12 / 54 ;$ F $5 / 56 ; F^{*} 1 / 68$ \\
\hline
\end{tabular}

Four-child families

$807 \mid$ M 4/63; M 9/64; $F^{*} 10 / 65 ;$ F 4/69

817 F 6/60; F 7/63; M 9/65; F* 4/67

$821 \quad M 10 / 54 ; M ~ 7 / 61 ; F^{*}$ e $6 / 67 ; M ~ 8 / 68$

$825 \mathrm{M}-149 ; \mathrm{M}-152 ; \mathrm{F}-/ 53 ; F^{*} 7 / 67$

825 M 5/55; M 3/57; M 2/59; F* 7/67

Five-child families

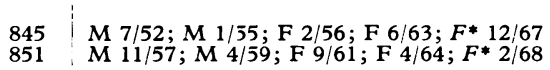

\begin{tabular}{r|r}
$7 / 36$ & $4 / 42$ \\
NK & NK \\
$9 / 34$ & $10 / 40$ \\
$9 / 42$ & $9 / 45$ \\
$4 / 25$ & $8 / 25$ \\
$12 / 28$ & $7 / 29$ \\
$6 / 30$ & $10 / 31$ \\
\hline
\end{tabular}

ANENCEPHALUS-MALES

One-child families

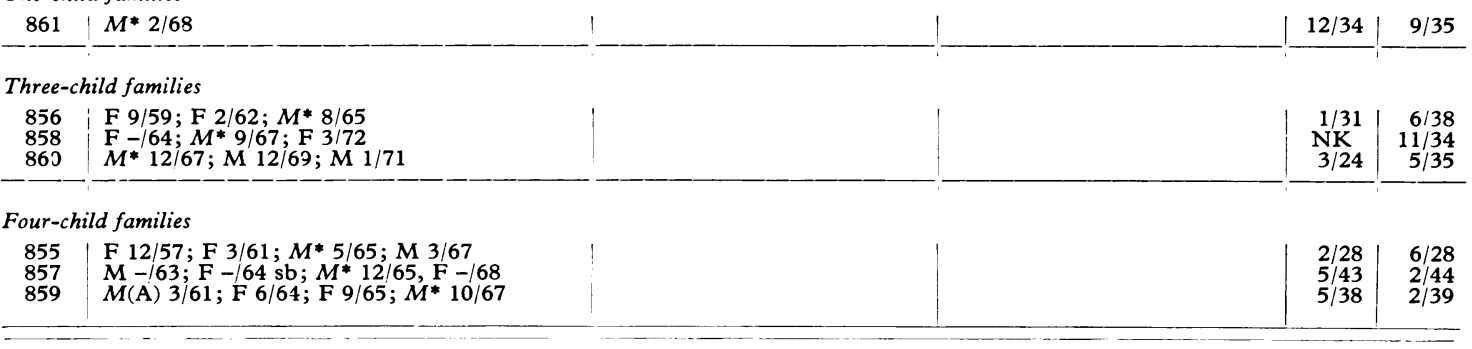

\section{ANENCEPHALUS-FEMALE}

Two-child families

\begin{tabular}{|c|c|c|c|c|}
\hline $\begin{array}{l}864 \\
869\end{array}$ & $\begin{array}{l}F(\mathrm{~A}) 10 / 61 ; F^{*} 9 / 65 \\
F(\mathrm{~S}) 5 / 66 \text { No. } 810 ; F^{*} 2 / 68\end{array}$ & F $10 / 68$ & $\begin{array}{r}11 / 39 \\
9 / 38\end{array}$ & $\begin{array}{r}11 / 41 \\
4 / 41\end{array}$ \\
\hline \multicolumn{5}{|c|}{ Three-child families } \\
\hline $\begin{array}{l}852 \\
863 \\
865 \\
867 \\
868 \\
\end{array}$ & $\begin{array}{l}F^{*} 4 / 65 ; M ~ 3 / 55 ; M 1 / 69 \\
\mathrm{~F}-164 ; F^{*} 7 / 65 ; M 4 / 69 \\
\mathrm{~F} 6 / 61 ; \mathrm{F} 8 / 64 ; F^{*} 7 / 66 \\
\mathrm{~F} 8 / 47 ; M(\mathrm{~S}) 2 / 55 ; F^{*} 12 / 66 \\
F^{*} 2 / 67 ; \mathrm{F} 4 / 68 ; M \text { S/69 }\end{array}$ & I & $\begin{array}{l}8 / 40 \\
\text { NK } \\
8 / 39 \\
9 / 23 \\
\text { NK }\end{array}$ & $\begin{array}{l}11 / 44 \\
\text { NK } \\
8 / 39 \\
9 / 26 \\
\text { NK }\end{array}$ \\
\hline \multicolumn{5}{|c|}{ Four-child families } \\
\hline 866 & F $1 / 63 ;$ M $11 / 64 ; F^{*} 7 / 66 ; M 8 / 68$ & & $12 / 38$ & $3 / 39$ \\
\hline
\end{tabular}




\section{Appendix III}

MALFORMATIONS (OTHER THAN THAT OF THE NEURAL TUBE) IN SIBS OF INDEX PATIENTS

\begin{tabular}{|c|c|}
\hline $\begin{array}{r}\text { Spina bifida } \\
\text { Family } 100 \\
132 \\
2 \\
71 \\
152 \\
300 \\
276 \\
490 \\
387 \\
345 \\
348 \\
379 \\
787\end{array}$ & $\begin{array}{l}\text { index patients } \\
\text { Cleft lip } \\
\text { Talipes } \\
\text { Congenital heart disease and pyloric stenosis } \\
\text { Congenital dislocation hip (both twins affected) } \\
\text { Pyloric stenosis } \\
\text { Hypospadias } \\
\text { Down's syndrome } \\
\text { Radial polydactyly } \\
\text { Congenital dislocation hip } \\
\text { Trigonencephaly } \\
\text { Congenital heart disease (transposition great vessels) } \\
\text { Down's syndrome } \\
\text { Bilateral talipes, club hand }\end{array}$ \\
\hline
\end{tabular}

Anencephaly index patients

Anencephaly index patients
Family 490 Klippel Feil, exomphalos and atresia aorta

426 Cleft palate

567 Congenital dislocation hip

676 Thyroglossal cyst

723 Congenital heart disease (ventricular septal defect)

724 Congenital deafness

525 Congenital heart disease

535 Acephalus and holocardius

619 Congenital heart disease and pyloric stenosis

617 Congenital dislocation hip

681 Congenital dislocation hip

620 Hirschsprung's disease

741 Congenital heart disease (ventricular septal defect)

745 Sacroccygeal tumour

704 Congenital heart disease

482 Hydrocephalus - gross with platybasia

857 Hydrocephalus-large internal 